\title{
Impact of uncertainties in inorganic chemical rate constants on tropospheric composition and ozone radiative forcing
}

\author{
Ben Newsome ${ }^{1}$ and Mat Evans ${ }^{1,2}$ \\ ${ }^{1}$ Wolfson Atmospheric Chemistry Laboratories, Department of Chemistry, University of York, York, YO10 5DD, UK \\ ${ }^{2}$ National Centre for Atmospheric Science, Department of Chemistry, University of York, York, YO10 5DD, UK \\ Correspondence to: Mat Evans (mat.evans@york.ac.uk)
}

Received: 5 January 2017 - Discussion started: 9 March 2017

Revised: 1 October 2017 - Accepted: 6 October 2017 - Published: 4 December 2017

\begin{abstract}
Chemical rate constants determine the composition of the atmosphere and how this composition has changed over time. They are central to our understanding of climate change and air quality degradation. Atmospheric chemistry models, whether online or offline, box, regional or global, use these rate constants. Expert panels evaluate laboratory measurements, making recommendations for the rate constants that should be used. This results in very similar or identical rate constants being used by all models. The inherent uncertainties in these recommendations are, in general, therefore ignored. We explore the impact of these uncertainties on the composition of the troposphere using the GEOS-Chem chemistry transport model. Based on the Jet Propulsion Laboratory (JPL) and International Union of Pure and Applied Chemistry (IUPAC) evaluations we assess the influence of 50 mainly inorganic rate constants and 10 photolysis rates on tropospheric composition through the use of the GEOSChem chemistry transport model.

We assess the impact on four standard metrics: annual mean tropospheric ozone burden, surface ozone and tropospheric $\mathrm{OH}$ concentrations, and tropospheric methane lifetime. Uncertainty in the rate constants for $\mathrm{NO}_{2}+\mathrm{OH} \stackrel{\mathrm{M}}{\longrightarrow} \mathrm{HNO}_{3}$ and $\mathrm{O}_{3}+\mathrm{NO} \rightarrow \mathrm{NO}_{2}+\mathrm{O}_{2}$ are the two largest sources of uncertainty in these metrics. The absolute magnitude of the change in the metrics is similar if rate constants are increased or decreased by their $\sigma$ values. We investigate two methods of assessing these uncertainties, addition in quadrature and a Monte Carlo approach, and conclude they give similar outcomes. Combining the uncertainties across the 60 reactions gives overall uncertainties on the annual mean tropospheric ozone burden, surface ozone and tropospheric $\mathrm{OH}$ concentrations, and tropospheric methane
\end{abstract}

lifetime of 10,11, 16 and $16 \%$, respectively. These are larger than the spread between models in recent model intercomparisons. Remote regions such as the tropics, poles and upper troposphere are most uncertain. This chemical uncertainty is sufficiently large to suggest that rate constant uncertainty should be considered alongside other processes when model results disagree with measurement.

Calculations for the pre-industrial simulation allow a tropospheric ozone radiative forcing to be calculated of $0.412 \pm 0.062 \mathrm{~W} \mathrm{~m}^{-2}$. This uncertainty $(13 \%)$ is comparable to the inter-model spread in ozone radiative forcing found in previous model-model intercomparison studies where the rate constants used in the models are all identical or very similar. Thus, the uncertainty of tropospheric ozone radiative forcing should expanded to include this additional source of uncertainty. These rate constant uncertainties are significant and suggest that refinement of supposedly well-known chemical rate constants should be considered alongside other improvements to enhance our understanding of atmospheric processes.

\section{Introduction}

The concentration of gases and aerosols in the atmosphere have changed over the last century due to human activity. This has resulted in a change in climate (IPCC, 2013) and a degradation in air quality (Dockery et al., 1993) with tropospheric ozone $\left(\mathrm{O}_{3}\right)$ and methane $\left(\mathrm{CH}_{4}\right)$ playing a central role. The response of these compounds to the changing emissions is complex and non-linear (Lin et al., 1988). The hydroxyl radical $(\mathrm{OH})$ plays a central role in this chemistry, as it ini- 
tiates the destruction of many pollutants (notably $\mathrm{CH}_{4}$ ) and thus determines their lifetime in the atmosphere. The dominant source of $\mathrm{OH}$ is the photolysis of $\mathrm{O}_{3}$ in the presence of water vapour. The oxidation of compounds such as $\mathrm{CH}_{4}$, carbon monoxide $(\mathrm{CO})$ and other hydrocarbons can lead to the production of $\mathrm{O}_{3}$ if sufficient oxides of nitrogen $\left(\mathrm{NO}_{x}\right)$ are present. Changes in the emissions of $\mathrm{O}_{3}$ precursors between the pre-industrial $(\sim 1850)$ and the present-day periods have increased $\mathrm{O}_{3}$ concentrations and this has produced a radiative forcing estimated to be $410 \pm 65 \mathrm{~mW} \mathrm{~m}^{-2}$ (Stevenson et al., 2013).

The rate constants of the reactions occurring in the atmosphere have been determined by a number of laboratory studies which are synthesised by groups such as the International Union of Pure and Applied Chemistry (IUPAC) (Atkinson et al., 2004) and Jet Propulsion Laboratory (JPL) (Burkholder et al., 2015) panels. These provide recommendations for both rate constants and their associated uncertainties. These reactions are typically expressed in an Arrhenius form to represent the temperature dependence. More complicated representations are needed for three-body reactions. IUPAC and JPL provide similar but different representations of the uncertainty in a rate constant. For IUPAC (Eq. 1), the uncertainty in a rate constant is described as the uncertainty in the $\log _{10}$ of the rate constant $\left(\Delta \log _{10} k_{T}\right)$ at a temperature $(T)$, with the panel giving values for the $\log _{10}$ uncertainty at $298 \mathrm{~K}\left(\Delta \log _{10} k_{298} \mathrm{~K}\right)$ and the rate of increase in uncertainty away from $298 \mathrm{~K}$ described by a $\Delta E / R$ term. For JPL (Eq. 1), the relative uncertainty in a rate constant $(f(T))$ is described as the relative uncertainty at temperature of $298 \mathrm{~K}$ $(f(298))$ together with a term $(g)$ that expresses how quickly the uncertainty increases away from $298 \mathrm{~K}$ (Eq. 2), leading to temperature dependences which increase away from room temperature (Fig. 1).

$$
\begin{aligned}
& \Delta \log _{10} k_{T}=\Delta \log _{10} k_{298} \mathrm{~K}+0.4343 \frac{\Delta E}{R}\left(\frac{1}{\mathrm{~T}}-\frac{1}{298 \mathrm{~K}}\right) \\
& f(T)=f(298 \mathrm{~K}) \exp \left|g\left(\frac{1}{\mathrm{~T}}-\frac{1}{298 \mathrm{~K}}\right)\right|
\end{aligned}
$$

For the reactions studied, the uncertainty at $298 \mathrm{~K}$ typically ranges from $5 \%$ for well-understood reactions to $30 \%$ for those which have significant uncertainties. Other reactions can have larger uncertainties than quoted here. The increase in uncertainty at temperatures away from $298 \mathrm{~K}$ can range from 0 to over $40 \%$, giving some reactions a total uncertainty of over $50 \%$ in the cold upper troposphere.

Models of atmospheric composition (whether using prescribed meteorology or calculating the meteorology, single box or transport, etc.) use these recommended rate constants, together with estimates of the meteorology, emissions, deposition, photolysis, etc. of compounds to calculate the concentration of species in the atmosphere. These models are a central tool for our understanding of atmospheric processes

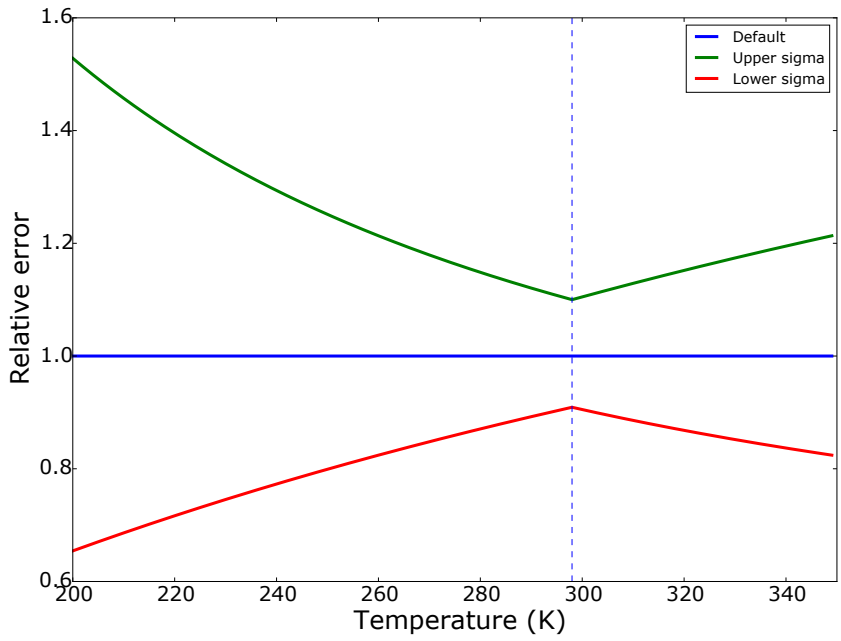

Figure 1. Example of the uncertainty on a reaction rate constant. The relative uncertainty of the reaction $\mathrm{O}_{3}+\mathrm{NO}$ is plotted as a function of temperature. The lowest uncertainty is at room temperature $(298 \mathrm{~K})$ with exponentially increasing uncertainties occurring as we diverge to higher and lower temperatures.

and for making policy choices to minimise climate change and air pollution.

Although these models have been developed significantly over the last decades, they have, in general, all used the same basic chemical rate constants as evaluated by the IUPAC or JPL panels. Little emphasis has been placed on understanding the uncertainty in predicted atmospheric composition caused by the uncertainty in these rate constants. The focus has been to investigate the impacts of novel chemical reactions or understanding emissions, etc. (e.g. Sherwen et al., 2016; Hartley and Prinn, 1993). Here though, we investigate the impact of this uncertainty on the composition of the troposphere. We base our assessment on the uncertainties in rate constants described by the JPL and IUPAC panels (Burkholder et al., 2015; Atkinson et al., 2004) using the GEOS-Chem model and evaluate a range of model diagnostics for both the present-day and the pre-industrial periods.

\section{Model simulations}

GEOS-Chem (Bey et al., 2001) (http://www.geos-chem.org) is an offline chemistry transport model. We use version 92. For computational expediency, we use a horizontal resolution of $4^{\circ}$ latitude by $5^{\circ}$ longitude with 47 vertical hybrid pressure-sigma levels from the surface to $0.01 \mathrm{hPa}$. The chemistry is solved within the troposphere with the SMVGEAR solver (Jacobson and Turco, 1994). We use a mass-based scheme for aerosol (Park et al., 2003) and thus can not investigate the impact of the rate constant uncertainty on aerosol number or size distribution. Stratospheric chemistry is unchanged in all simulations and uses a lin- 
earised approach to the chemistry (McLinden et al., 2000; Murray et al., 2012). Global anthropogenic emissions were taken from the Emission Database for Global Atmospheric Research (EDGAR) v3 for $\mathrm{NO}_{x}, \mathrm{CO}$, VOCs and $\mathrm{SO}_{x}$. Regional or source-specific inventories replaced EDGAR where appropriate (EMEP, BRAVO, Streets, CAC, NEI05, RETRO and AEIC; see the GEOS-Chem wiki for more details). Biogenic emissions (isoprene, monoterpenes, methyl butenol) are taken from the MEGAN v2.1 emission inventory (Sindelarova et al., 2014). Biomass burning emissions were used from the GFED3 monthly emission inventory (van der Werf et al., 2010). $\mathrm{NO}_{x}$ sources from lightning (Murray et al., 2012) and soils (Hudman et al., 2012) were also included. As in previous studies (Parrella et al., 2012; Sofen et al., 2011), pre-industrial emissions are calculated by switching off anthropogenic emissions, reducing biomass burning emissions to $10 \%$ of their modern-day values and setting $\mathrm{CH}_{4}$ concentrations to a constant 700 ppbv (Parrella et al., 2012).

For both present-day and the pre-industrial simulations, we run the model from 1 July 2005 to 1 July 2007 with GEOS-5 meteorology. We used the first year to spin up the composition of the troposphere. Metrics are derived from the second year of simulation.

We follow the methodology of JPL (Burkholder et al., 2015) for the representation of uncertainties in rate constants converting IUPAC representation where necessary. For twobody reactions, the uncertainty is given by two parameters. $f(298 \mathrm{~K})$ describes the relative uncertainty at $298 \mathrm{~K}$, and $g$ describes how the uncertainty increases as temperature diverges from $298 \mathrm{~K}$, as shown in Eq. (2).

\section{Reactions studied}

We limit our study to the inorganic $\left(\mathrm{O}_{x}, \mathrm{HO}_{x}, \mathrm{NO}_{x}, \mathrm{CO}\right.$, $\mathrm{CH}_{4}$ ) reactions together with some key organic and sulfur reactions. Uncertainties in organic molecules degradation chemistry of the atmosphere makes a systematic assessment of these uncertainties difficult (Goldstein and Galbally, 2007). Table 1 shows a list of reactions that are perturbed and the uncertainties assumed. We use the uncertainty recommendations from the JPL panel if provided and the IUPAC panel otherwise. We investigate the impact of 50 inorganic chemical reactions and 10 photolysis reactions (Table 1). Uncertainties in photolysis rate constants are harder to define than for the other reactions. We consider the appropriate chemical uncertainty here as the uncertainty in the absorption cross section and the quantum yield rather than the uncertainty in the photon flux which we attribute to the radiative transfer calculation. A full calculation of the chemical uncertainty in a photolysis rate is complex, as it depends upon the uncertainties at different wavelengths, the independence of the cross section and quantum yield parameters and the transfer of this information through the spectral bins used for the laboratory studies and the photolysis calculations. In order to simplify this calculation, we apply a $10 \%$ uncertainty to all photolysis rates. Although this is not ideal, it does allow us to place an uncertainty in the photolysis rates into the context of other uncertainties. An improved presentation of the photolysis uncertainty should be included in future work.

\section{Single reaction perturbations}

From each of these 60 reactions, we increase the reaction rate by the $1 \sigma$ temperature-dependent uncertainty given in Table 1. To allow the model to spin up, we run the model for 2 years and take the second year of simulation for the calculation of four metrics: tropospheric $\mathrm{O}_{3}$ burden, mean surface $\mathrm{O}_{3}$ mixing ratio, tropospheric mass-weighted mean $\mathrm{OH}$ number density and tropospheric mean $\mathrm{CH}_{4}$ lifetime. We subtract the values of these metrics from the base value of the metric (unchanged rate constants) and then take the absolute value to remove cases where the value decreases on an increase in the rate constant. Figure 2 shows the changes for all four metrics with Table 1 giving the values for the change in tropospheric $\mathrm{O}_{3}$ burden. We express these values as a percentage of the base case value.

It is evident that a relatively small number of reactions produce large uncertainties in the values of these metrics. The one that offers the most uncertainty is the reaction between $\mathrm{NO}_{2}$ and $\mathrm{OH}$ to product nitric acid, which leads to uncertainties in the range of $6-11 \%$ in the metrics investigated here. This reaction is both highly uncertain $(f(298 \mathrm{~K})=30 \%)$ and acts as a large global sink for $\mathrm{NO}_{x}$ and $\mathrm{HO}_{x}$. The $\mathrm{O}_{3}+\mathrm{NO}$ reaction to produce $\mathrm{NO}_{2}$ is central to the partitioning of $\mathrm{NO}_{x}$ in the atmosphere. Thus, increasing its rate constant reduces $\mathrm{NO}$ concentrations in the atmosphere (leading to lower $\mathrm{O}_{3}$ concentrations) and increasing the concentration of $\mathrm{NO}_{2}$ (which favours $\mathrm{NO}_{2}$ removal) which again reduces $\mathrm{O}_{3}$ concentrations. Another significant reaction is that between $\mathrm{CH}_{4}$ and $\mathrm{OH}$ to produce $\mathrm{CH}_{3} \mathrm{O}_{2}$ radicals. The model assumes a constant $\mathrm{CH}_{4}$ concentration so an increase in the rate constant between $\mathrm{CH}_{4}$ and $\mathrm{OH}$ leads to an increased source of radicals but does not lead to a commensurate drop in the $\mathrm{CH}_{4}$ concentration. Thus, an increase in this rate constant in the model is effectively the same as an increase in the emission of $\mathrm{CH}_{4}$, which results in a wide range of impacts such as increased $\mathrm{CO}$ concentrations, etc. Reactions after the 10th most significant reaction for all the metrics generates an uncertainty of less than $1 \%$.

The relative importance of the different reactions does not change much with the metric being investigated (see Fig. 2). The rate constants of these top 10 reactions are not particularly uncertain (other than for $\mathrm{NO}_{2}+\mathrm{OH}$ ) compared to other reactions, but they link important chemical cycles and have a very large chemical flux flowing through them. Thus, relatively small changes in their uncertainties will lead to large changes in concentration. 
Table 1. Table of reactions studied. $f(298)$ indicates the JPL or IUPAC panel uncertainty estimate at $298 \mathrm{~K}$ and $g$ gives the rate at which this uncertainty increases away from $298 \mathrm{~K}$ (see previous section). Reactions with 0 for the temperature dependence indicate there is zero temperature dependency or not enough information to provide a temperature-varying uncertainty. The final column gives the fractional increase in the ozone burden by increasing the rate constant to its $1 \sigma$ value. Reactions with a* are the 10 reactions used in the Monte Carlo study.

\begin{tabular}{|c|c|c|c|c|}
\hline Number & Reaction & $f(298)$ & $g(\mathrm{~K})$ & $\begin{array}{r}1 \sigma \mathrm{O}_{3} \text { burden } \\
\text { change }(\%)\end{array}$ \\
\hline $1^{*}$ & $\mathrm{NO}_{2}+\mathrm{OH} \stackrel{\mathrm{M}}{\longrightarrow} \mathrm{HNO}_{3}$ & 1.3 & 100 & -6.20 \\
\hline $2^{*}$ & $\mathrm{O}_{3}+\mathrm{NO} \rightarrow \mathrm{NO}_{2}+\mathrm{O}_{2}$ & 1.1 & 200 & -3.61 \\
\hline $3^{*}$ & $\mathrm{HO}_{2}+\mathrm{NO} \rightarrow \mathrm{NO}_{2}+\mathrm{OH}$ & 1.15 & 20 & 3.09 \\
\hline $4^{*}$ & $\mathrm{OH}+\mathrm{CH}_{4} \rightarrow \mathrm{CH}_{3} \mathrm{O}_{2}+\mathrm{H}_{2} \mathrm{O}$ & 1.1 & 100 & 2.89 \\
\hline $5^{*}$ & $\mathrm{O}_{3}+\mathrm{HO}_{2} \rightarrow \mathrm{OH}+2 \mathrm{O}_{2}$ & 1.15 & 80 & -2.39 \\
\hline $6^{*}$ & $\mathrm{O}\left({ }^{1} \mathrm{D}\right)+\mathrm{N}_{2} \rightarrow \mathrm{O}+\mathrm{N}_{2}$ & 1.1 & 20 & 1.82 \\
\hline $7^{*}$ & $\mathrm{O}\left({ }^{1} \mathrm{D}\right)+\mathrm{H}_{2} \mathrm{O} \rightarrow \mathrm{OH}+\mathrm{OH}$ & 1.08 & 20 & -1.54 \\
\hline 8 & $\mathrm{HO}_{2}+\mathrm{NO}_{2} \stackrel{\mathrm{M}}{\longrightarrow} \mathrm{HNO}_{4}$ & 1.06 & 400 & -0.959 \\
\hline 9 & $\mathrm{HNO}_{3}+\mathrm{OH} \rightarrow \mathrm{H}_{2} \mathrm{O}+\mathrm{NO}_{3}$ & 1.2 & 0 & 0.928 \\
\hline $10^{*}$ & $\mathrm{O}_{3}+\mathrm{NO}_{2} \rightarrow \mathrm{NO}_{3}+\mathrm{O}_{2}$ & 1.15 & 150 & -0.803 \\
\hline $11^{*}$ & $\mathrm{O}\left({ }^{1} \mathrm{D}\right)+\mathrm{O}_{2} \rightarrow \mathrm{O}+\mathrm{O}_{2}$ & 1.1 & 10 & 0.745 \\
\hline 12 & $\mathrm{CH}_{3} \mathrm{C}(\mathrm{O}) \mathrm{O}_{2}+\mathrm{NO} \rightarrow \mathrm{CH}_{3} \mathrm{O}_{2}+\mathrm{NO}_{2}+\mathrm{CO}_{2}$ & 1.5 & 0 & 0.721 \\
\hline $13^{*}$ & $\mathrm{O}_{3}+\mathrm{OH} \rightarrow \mathrm{HO}_{2}+\mathrm{O}_{2}$ & 1.1 & 50 & -0.693 \\
\hline 14 & $\mathrm{CH}_{3} \mathrm{O}_{2}+\mathrm{NO} \rightarrow \mathrm{CH}_{2} \mathrm{O}+\mathrm{HO}_{2}+\mathrm{NO}_{2}$ & 1.15 & 100 & 0.553 \\
\hline 15 & $\mathrm{CH}_{3} \mathrm{OH}+\mathrm{OH} \rightarrow \mathrm{HO}_{2}+\mathrm{CH}_{2} \mathrm{O}$ & 1.1 & 60 & 0.462 \\
\hline 16 & $\mathrm{CH}_{3} \mathrm{C}(\mathrm{O}) \mathrm{OONO}_{2} \rightarrow \mathrm{CH}_{3} \mathrm{C}(\mathrm{O}) \mathrm{OO}+\mathrm{NO}_{2}$ & 1.2 & 200 & 0.341 \\
\hline 17 & $\mathrm{CH}_{3} \mathrm{C}(\mathrm{O}) \mathrm{O}_{2}+\mathrm{NO}_{2} \stackrel{\mathrm{M}}{\longrightarrow} \mathrm{CH}_{3} \mathrm{C}(\mathrm{O}) \mathrm{OONO}$ & 1.2 & 50 & -0.289 \\
\hline 18 & $\mathrm{OH}+\mathrm{H}_{2} \rightarrow \mathrm{H}_{2} \mathrm{O}+\mathrm{HO}_{2}$ & 1.05 & 100 & 0.282 \\
\hline 29 & $\mathrm{OH}+\mathrm{H}_{2} \mathrm{O}_{2} \rightarrow \mathrm{H}_{2} \mathrm{O}+\mathrm{HO}_{2}$ & 1.15 & 45 & 0.265 \\
\hline 20 & $\mathrm{NO}+\mathrm{NO}_{3} \rightarrow 2 \mathrm{NO}_{2}$ & 1.3 & 100 & 0.249 \\
\hline 21 & $\mathrm{HO}_{2}+\mathrm{NO}_{3} \rightarrow \mathrm{OH}+\mathrm{NO}_{2}$ & 1.5 & 0 & 0.248 \\
\hline 22 & $\mathrm{CH}_{3} \mathrm{OOH}+\mathrm{OH} \rightarrow \mathrm{CH}_{3} \mathrm{O}_{2}+\mathrm{H}_{2} \mathrm{O}$ & 1.4 & 150 & -0.243 \\
\hline 23 & $\mathrm{CH}_{3} \mathrm{SCH}_{3}+\mathrm{OH} \rightarrow \mathrm{SO}_{2}+\mathrm{CH}_{3} \mathrm{O}_{2}+\mathrm{CH}_{2} \mathrm{O}$ & 1.1 & 100 & 0.231 \\
\hline 24 & $\mathrm{OH}+\mathrm{HO}_{2} \rightarrow \mathrm{H}_{2} \mathrm{O}+\mathrm{O}_{2}$ & 1.15 & 50 & -0.215 \\
\hline 25 & $\mathrm{CH}_{3} \mathrm{CH}_{2} \mathrm{OO}+\mathrm{NO} \rightarrow \mathrm{CH}_{3} \mathrm{CHO}+\mathrm{NO}_{2}+\mathrm{HO}_{2}$ & 1.2 & 150 & 0.211 \\
\hline 26 & $\mathrm{C}_{2} \mathrm{H}_{6}+\mathrm{OH} \rightarrow \mathrm{CH}_{3} \mathrm{CH}_{2} \mathrm{OO}+\mathrm{H}_{2} \mathrm{O}$ & 1.07 & 50 & 0.201 \\
\hline 27 & $\mathrm{O}\left({ }^{1} \mathrm{D}\right)+\mathrm{H}_{2} \rightarrow \mathrm{OH}+\mathrm{H}$ & 1.15 & 50 & 0.198 \\
\hline 28 & $\mathrm{HCOOH}+\mathrm{OH} \rightarrow \mathrm{H}_{2} \mathrm{O}+\mathrm{CO}_{2}+\mathrm{HO}_{2}$ & 1.2 & 100 & 0.196 \\
\hline 29 & $\mathrm{OH}+\mathrm{OH} \rightarrow \mathrm{H}_{2} \mathrm{O}+\mathrm{O}_{3}$ & 1.25 & 50 & 0.195 \\
\hline 30 & $\mathrm{CH}_{3} \mathrm{CHO}+\mathrm{NO}_{3} \rightarrow \mathrm{HNO}_{3}+\mathrm{CH}_{3} \mathrm{C}(\mathrm{O}) \mathrm{OO}$ & 1.3 & 300 & 0.193 \\
\hline 31 & $\mathrm{HNO}_{2}+\mathrm{OH} \rightarrow \mathrm{H}_{2} \mathrm{O}+\mathrm{NO}_{2}$ & 1.5 & 200 & 0.178 \\
\hline 32 & $\mathrm{CH}_{3} \mathrm{CHO}+\mathrm{OH} \rightarrow \mathrm{CH}_{3} \mathrm{C}(\mathrm{O}) \mathrm{OO}+\mathrm{CH}_{2} \mathrm{O}+\mathrm{CO}+\mathrm{HO}_{2}$ & 1.05 & 20 & 0.174 \\
\hline 33 & $\mathrm{CH}_{3} \mathrm{SCH}_{3}+\mathrm{NO}_{3} \rightarrow \mathrm{SO}_{2}+\mathrm{HNO}_{3}+\mathrm{CH}_{3} \mathrm{OO}+\mathrm{CH}_{2} \mathrm{O}$ & 1.1 & 150 & 0.172 \\
\hline 34 & $\mathrm{CH}_{3} \mathrm{O}_{2}+\mathrm{CH}_{3} \mathrm{O}_{2} \rightarrow \mathrm{CH}_{3} \mathrm{OH}+\mathrm{CH}_{2} \mathrm{O}+\mathrm{O}_{2}$ & 1.2 & 100 & 0.170 \\
\hline 35 & $\mathrm{HO}_{2}+\mathrm{HO}_{2} \rightarrow \mathrm{H}_{2} \mathrm{O}_{2}$ & 1.15 & 100 & 0.166 \\
\hline 36 & $\mathrm{CH}_{2} \mathrm{O}+\mathrm{OH} \rightarrow \mathrm{CO}+\mathrm{HO}_{2}+\mathrm{H}_{2} \mathrm{O}$ & 1.15 & 50 & 0.156 \\
\hline 37 & $\mathrm{NO}+\mathrm{OH} \stackrel{\mathrm{M}}{\longrightarrow} \mathrm{HNO}_{2}$ & 1.2 & 50 & -0.151 \\
\hline 38 & $\mathrm{SO}_{2}+\mathrm{OH} \stackrel{\mathrm{M}}{\longrightarrow} \mathrm{SO}_{4}+\mathrm{HO}_{2}$ & 1.1 & 100 & 0.151 \\
\hline 39 & $\mathrm{NO}_{2}+\mathrm{NO}_{3} \stackrel{\mathrm{M}}{\longrightarrow} \mathrm{N}_{2} \mathrm{O}_{5}$ & 1.2 & 100 & -0.151 \\
\hline 40 & $\mathrm{HNO}_{4}+\mathrm{OH} \rightarrow \mathrm{H}_{2} \mathrm{O}+\mathrm{NO}_{2}+\mathrm{O}_{2}$ & 1.3 & 500 & 0.149 \\
\hline 41 & $\mathrm{OH}+\mathrm{OH} \stackrel{\mathrm{M}}{\longrightarrow} \mathrm{H}_{2} \mathrm{O}_{2}$ & 1.5 & 100 & -0.146 \\
\hline 42 & $\mathrm{CO}+\mathrm{OH} \rightarrow \mathrm{HO}_{2}+\mathrm{CO}_{2}$ & 1.1 & 100 & -0.144 \\
\hline 43 & $\mathrm{NO}_{3}+\mathrm{NO}_{3} \rightarrow 2 \mathrm{NO}_{2}+\mathrm{O}_{2}$ & 1.5 & 500 & -0.144 \\
\hline 44 & $\mathrm{OH}+\mathrm{NO}_{3} \rightarrow \mathrm{HO}_{2}+\mathrm{NO}_{2}$ & 1.5 & 0 & -0.143 \\
\hline 45 & $\mathrm{NO}_{2}+\mathrm{NO}_{3} \rightarrow \mathrm{NO}+\mathrm{NO}_{2}+\mathrm{O}_{2}$ & 1.1 & 100 & -0.134 \\
\hline 46 & $\mathrm{HNO}_{4} \rightarrow \mathrm{HO}_{2}+\mathrm{NO}_{2}$ & 1.3 & 270 & 0.104 \\
\hline 47 & $\mathrm{CH}_{3} \mathrm{O}_{3}+\mathrm{HO}_{2} \rightarrow \mathrm{CH}_{3} \mathrm{OOH}+\mathrm{O}_{2}$ & 1.3 & 150 & 0.0350 \\
\hline 48 & $\mathrm{CH}_{2}=\mathrm{C}\left(\mathrm{CH}_{3}\right) \mathrm{CH}=\mathrm{CH}_{2}+\mathrm{OH} \rightarrow \mathrm{HOCH}_{2} \mathrm{C}(\mathrm{OO})\left(\mathrm{CH}_{3}\right) \mathrm{CH}=\mathrm{CH}_{2}$ & 1.07 & 100 & -0.0323 \\
\hline
\end{tabular}


Table 1. Continued.

\begin{tabular}{llrrr}
\hline Number & Reaction & $f(298)$ & $g(\mathrm{~K})$ & $\begin{array}{r}1 \sigma \mathrm{O}_{3} \text { burden } \\
\text { change }(\%)\end{array}$ \\
\hline 49 & $\mathrm{NO}_{3}+\mathrm{CH}_{2} \mathrm{O} \rightarrow \mathrm{HNO}_{3}+\mathrm{HO}_{2}+\mathrm{CO}$ & 1.3 & 0 & -0.0145 \\
50 & $\mathrm{C}_{4} \mathrm{H}_{10}+\mathrm{OH} \rightarrow 2 \mathrm{H}_{2} \mathrm{O}+\mathrm{C}_{4} \mathrm{H}_{9}$ & 1.06 & 100 & 0.0132 \\
\hline 51 & $\left.h v+\mathrm{NO}_{2} \rightarrow \mathrm{NO}+\mathrm{O}^{3} \mathrm{P}\right)$ & 1.1 & 0 & 2.66 \\
52 & $h v+\mathrm{O}_{3} \rightarrow \mathrm{O}_{2}+\mathrm{O}\left({ }^{1} \mathrm{D}\right)$ & 1.1 & 0 & -1.97 \\
53 & $h v+\mathrm{HNO}_{3} \rightarrow \mathrm{OH}+\mathrm{NO}_{2}$ & 1.1 & 0 & 0.559 \\
54 & $h v+\mathrm{CH}_{2} \mathrm{O} \rightarrow \mathrm{CO}+\mathrm{HO}_{2}+\mathrm{HO}_{2}$ & 1.1 & 0 & 0.338 \\
55 & $h v+\mathrm{HNO}_{4} \rightarrow \mathrm{HO}_{2}+\mathrm{NO}_{2}$ & 1.1 & 0 & 0.262 \\
56 & $h v+\mathrm{N}_{2} \mathrm{O}_{5} \rightarrow \mathrm{NO}_{3}+\mathrm{NO}_{2}$ & 1.1 & 0 & 0.223 \\
57 & $\left.h v+\mathrm{NO}_{3} \rightarrow \mathrm{NO}_{2}+\mathrm{O}^{3} \mathrm{P}\right)$ & 1.1 & 0 & 0.222 \\
58 & $h v+\mathrm{HNO}_{4} \rightarrow \mathrm{OH}^{2} \mathrm{NO}_{3}$ & 1.1 & 0 & 0.200 \\
59 & $h v+\mathrm{CH}_{3} \mathrm{CHO} \rightarrow \mathrm{CH}_{3} \mathrm{OO}+\mathrm{HO}_{2}+\mathrm{CO}$ & 1.1 & 0 & 0.199 \\
60 & $h v+\mathrm{CH}_{3} \mathrm{CHO} \rightarrow \mathrm{CH}_{4}+\mathrm{CO}$ & 1.1 & 0 & 0.196 \\
\hline
\end{tabular}
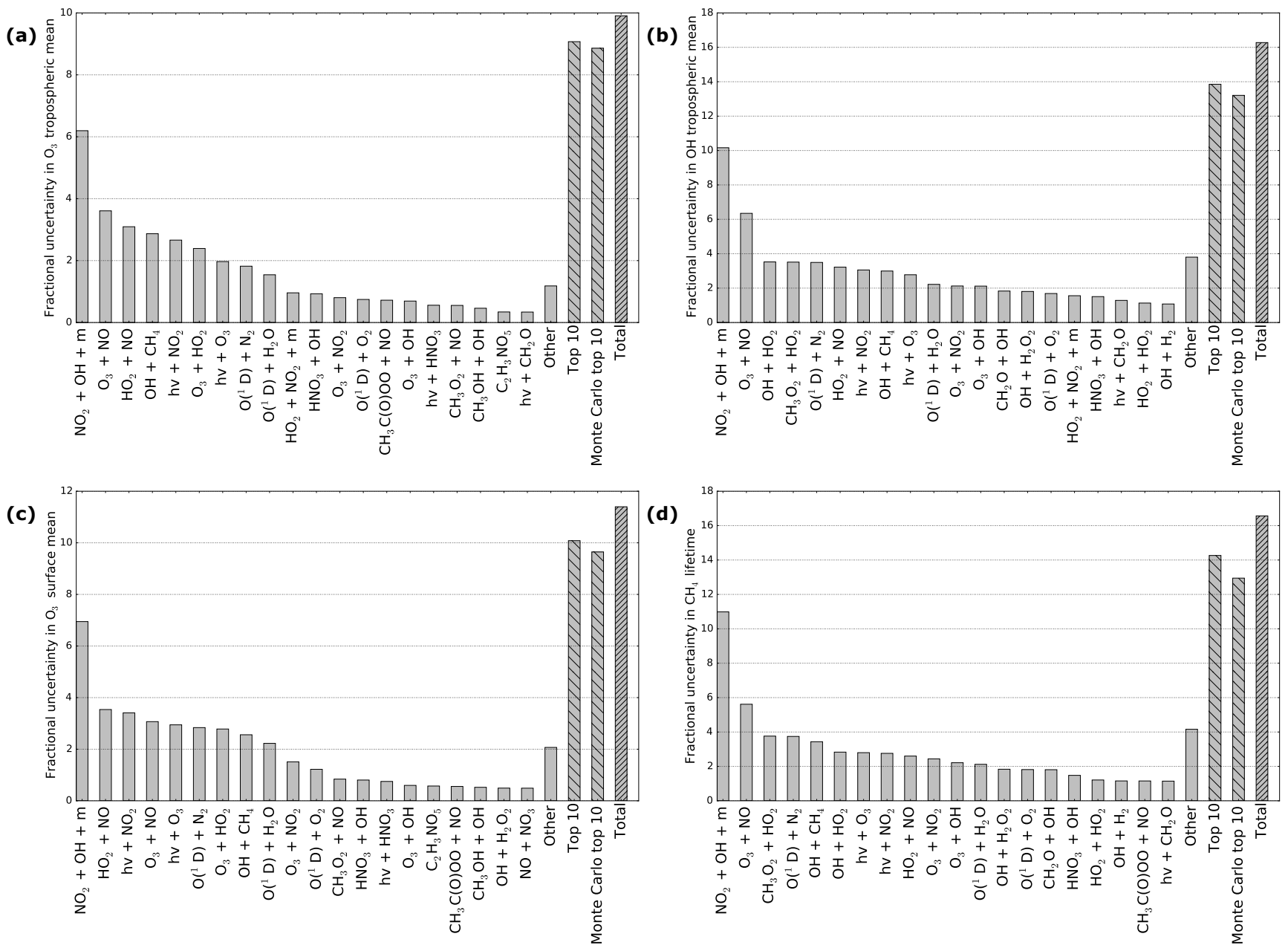

Figure 2. Uncertainties in all metrics: fractional uncertainties of (a) $\mathrm{O}_{3}$ tropospheric burden, (b) $\mathrm{OH}$ tropospheric burden, (c) $\mathrm{O}_{3}$ surface concentration and (d) $\mathrm{CH}_{4}$ lifetime. Each bar labelled with a reaction represents a run with a $1 \sigma$ increase in the rate constant. "Other" represents the addition in quadrature of the reactions that were not the top 20 most influential. "Top 10" represents the addition in quadrature of the 10 most important reactions, and "Monte Carlo top 10" represents the standard deviation of the Monte Carlo ensemble. "Total" represents the addition in quadrature of all the simulations. 

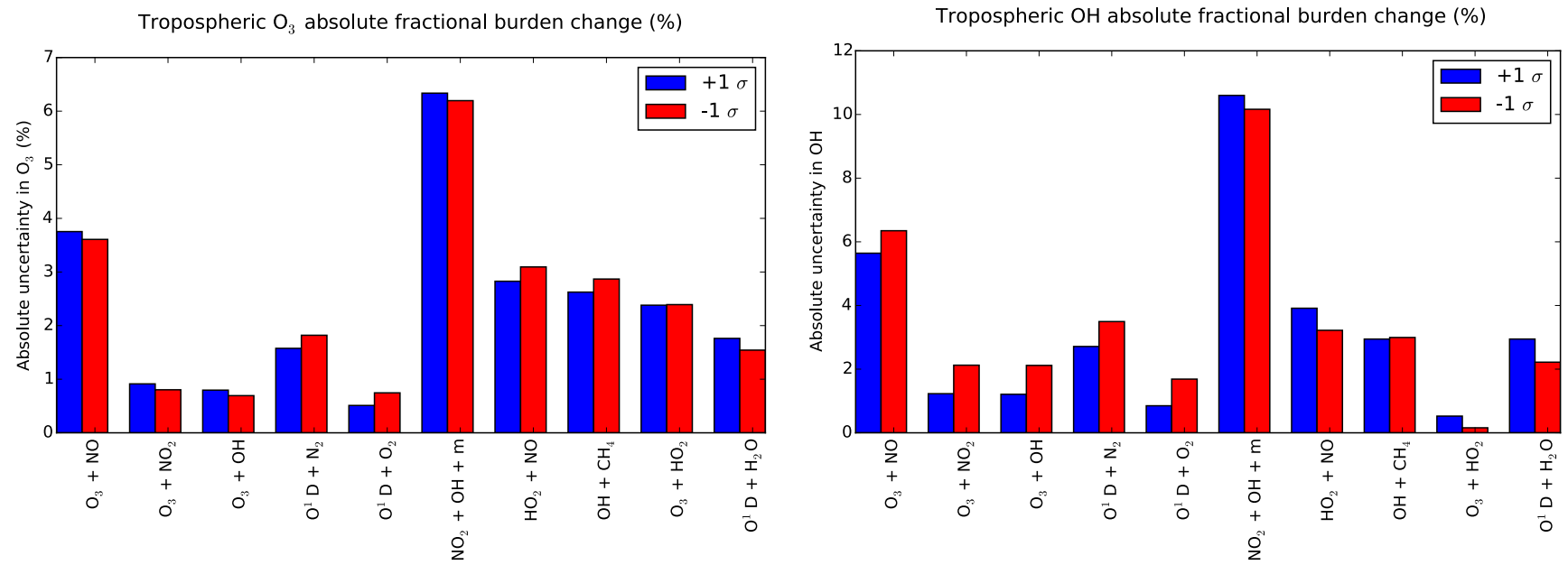

Figure 3. Uncertainty linearity: a comparison of absolute uncertainties in $\mathrm{O}_{3}$ and $\mathrm{OH}$ tropospheric burdens for both positive and negative changes to the rate constants. These reactions show a similar magnitude of tropospheric species concentration change if the rate is set to its lower or higher sigma level of uncertainty.

It is just as easy to decrease the rate constants as it is to increase them. Figure 3 shows that the absolute uncertainties in tropospheric $\mathrm{O}_{3}$ burden and $\mathrm{OH}$ global mean concentrations vary for the top 10 reactions for both increasing and decreasing the rate constant. Although there are some differences between the impact of increasing or decreasing the rate constant, there is a degree of consistency between the two, and so for simplicity reasons we only consider further the impact of increasing the rate constants.

Given the uncertainties for the individual reactions calculated here, the next question is how these uncertainties can be combined together to generate a single uncertainty from rate constants' uncertainty on the composition of the atmosphere.

\section{Addition of uncertainties}

If these perturbations are independent (uncertainties in one rate constant are not related to uncertainties in another) and the model approximately linear, the total rate constant uncertainty can be found by finding the root of the sum of the individual uncertainties squared (addition in quadrature) as shown in Eq. (3).

$\sigma_{\text {total }}^{2}=\Sigma \sigma_{\text {reaction }}^{2}$

It is hard to assess the independence of the rate constants. Given the nature of the laboratory experiments used to determine them, it is likely that there is some overlap in assumptions. It would be extremely difficult to diagnose this for all 60 reactions, and so we ignore this in further work.

Atmospheric chemistry is though non-linear (Lin et al., 1988). A doubling of a change to the model does not necessarily lead to a doubling of the model response. Thus, is it not obvious how uncertainties from the individual rate con- stant perturbations should be combined. To investigate this, we perform a Monte Carlo analysis of the model. We take 10 of the most significant reactions determined earlier (shown by the * in Table 1) and generate 10 normally distributed random numbers $(\mu=0, \sigma=1)$, one for each reaction. For each of the 10 rate constants, we add on the calculated $1 \sigma$ uncertainty multiplied by the random number and run the model. We repeat this 50 times to produce a Monte Carlo ensemble from which we can calculate the four metrics described earlier.

If the model is linear, the metrics calculated from each member of the Monte Carlo ensemble should be (to some level) the same as the linear addition of the individual rate constant perturbations weighted by the Monte Carlo random numbers. Figure 4 shows the perturbation in the value of the metric calculated for each ensemble member against the calculated value of the metric using the single reaction values. The model shows a strong linear relationship between the metrics examined (intercepts of $0.21 \pm 0.9 \%$ and gradients of $0.80 \pm 0.04$ ); thus, if the errors are uncorrelated, we can, at least to a first approximation, add the individual $1 \sigma$ perturbations together in quadrature using Eq. (3) to calculate the overall uncertainty in the model metrics. From these simulations, we estimate the quadrature approach leads to an overestimate of the $1 \sigma$ uncertainty on the order of $10 \%$.

We thus conclude that the adding together of the individual perturbations in quadrature gives a good approximation to the uncertainty calculated by the Monte Carlo method for significantly less computational burden. 
$\mathrm{O}_{3}$ tropospheric mean
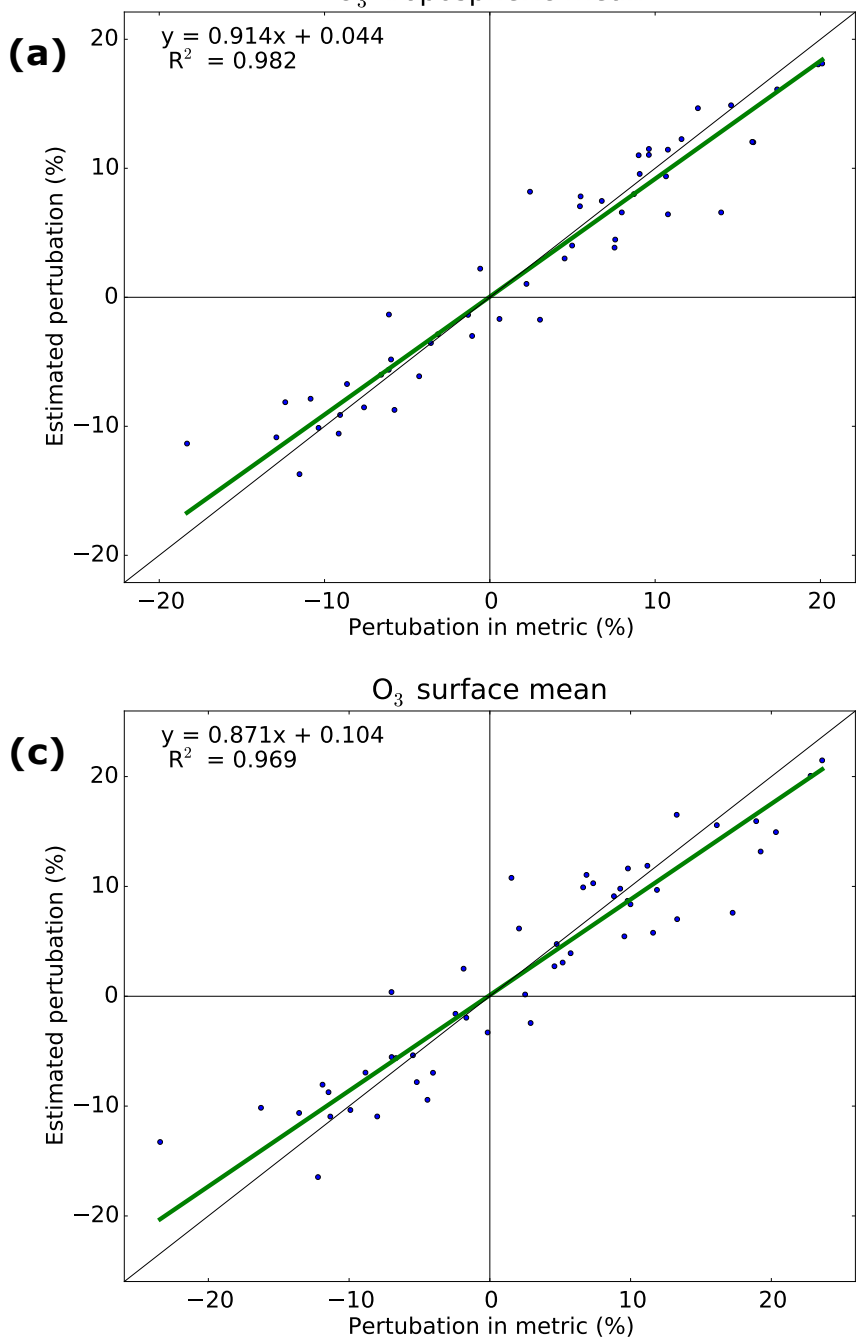

$\mathrm{OH}$ tropospheric mean
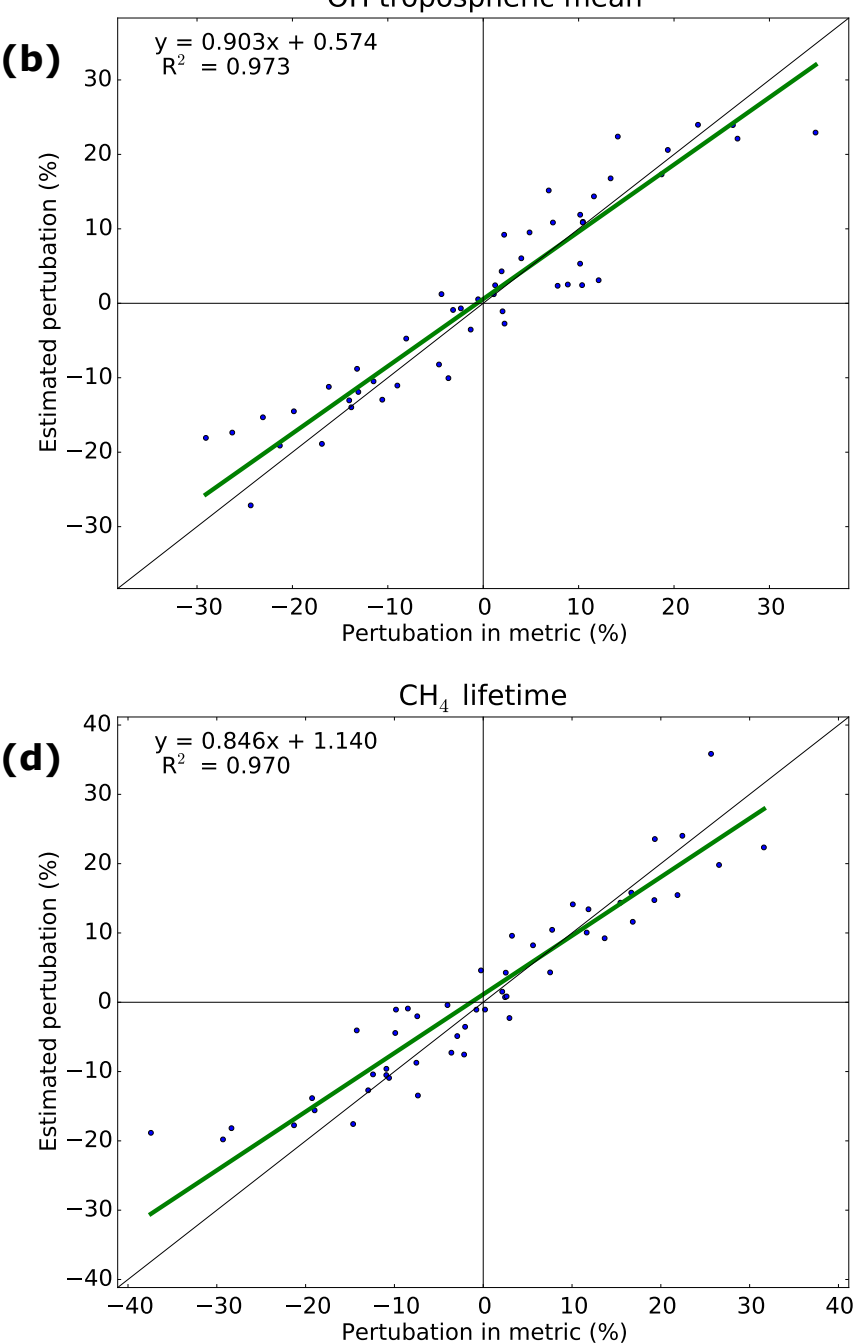

Figure 4. Monte Carlo simulations to understand the models' linearity: the $x$-axis values show the percentage change in the metric value of an ensemble member compared to the simulation with no perturbations. The $y$-axis values show the expected percentage change of the metric based on a linear addition of the individual $1 \sigma$ perturbation experiments weighted by the Monte Carlo perturbation values. Metrics investigated are (a) $\mathrm{O}_{3}$ tropospheric burden, (b) $\mathrm{OH}$ tropospheric burden, (c) $\mathrm{O}_{3}$ mean surface concentration and (d) $\mathrm{CH}_{4}$ lifetime. We show the result of 50 Monte Carlo simulations. Each simulation perturbs 10 of the most important reactions $\left({ }^{*}\right.$ reactions in Table 1$) 1 \sigma$ by normally distributed random numbers.

\section{Impacts on the present-day atmosphere metrics}

We show in Fig. 2 the absolute percentage change in global annual mean $\mathrm{O}_{3}$ burden, surface $\mathrm{O}_{3}$, tropospheric average $\mathrm{OH}$ and $\mathrm{CH}_{4}$ tropospheric lifetime from increasing each of the reaction rate constants in Table 1 in turn by their $1 \sigma$ value. They are ordered by the magnitude of the perturbation, and for clarity we only show the top 20 , combining the remaining 40 in quadrature into the "Other" category. The fractional change in tropospheric $\mathrm{O}_{3}$ burden for all of the perturbations is given in Table 1. We show the results of combining all of these reactions in quadrature ("Total (sum)"), the result of combining the top 10 in quadrature ("Top 10") and the standard deviation from the 50 Monte Carlo simulations ("Monte Carlo top 10"). The relative closeness ( $\sim 10 \%)$ of the value calculated from the "Top 10" and the "Monte Carlo top 10" shows that the addition in quadrature approach provides a useful approximation to the Monte Carlo methodology with significantly less computational burden.

The top 10 reactions contribute over $90 \%$ of the uncertainty for all metrics with the overall uncertainty for the annual mean tropospheric ozone burden, surface ozone and tropospheric $\mathrm{OH}$ concentrations, and tropospheric methane lifetime calculated to be $10,11,16$ and $16 \%$, respectively. These uncertainties can be compared to the inter-model spreads found from model intercomparison exercises. The multi- 
(a)
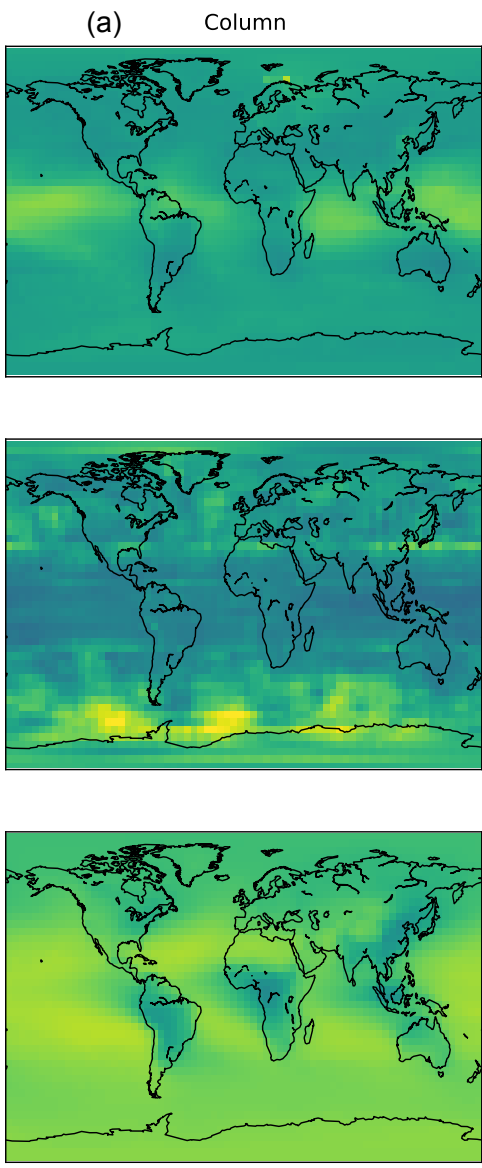

(b) Zonal
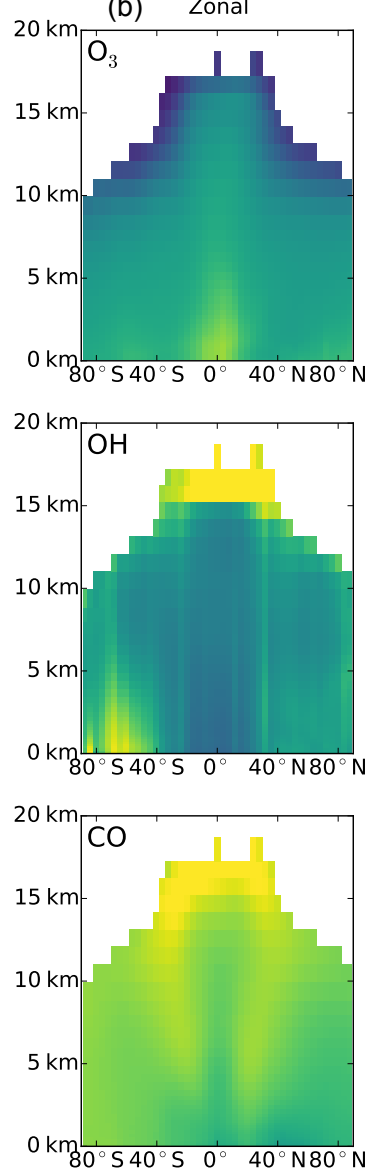

(c)
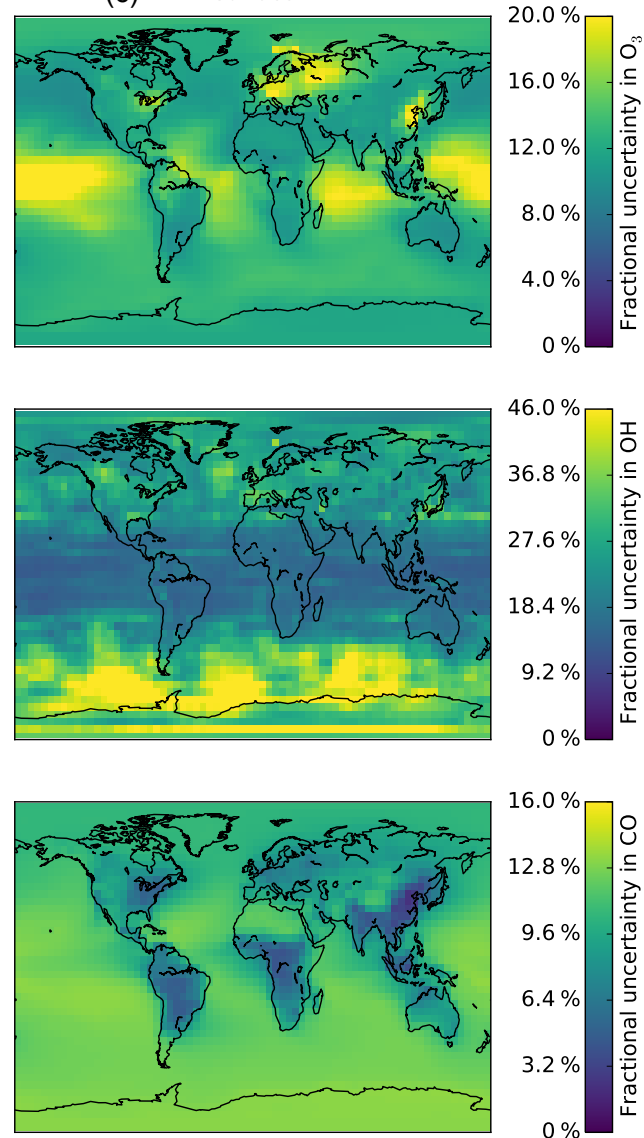

Figure 5. Spatial distribution of uncertainties: fractional uncertainties calculated for $\mathrm{O}_{3}, \mathrm{OH}$ and $\mathrm{CO}$ concentrations for the tropospheric column (a), the zonal mean (b) and the surface (c) from adding together the individual reaction uncertainties from the 60 reactions studied in quadrature.

model standard deviations in the ozone burden, tropospheric $\mathrm{OH}$ concentration and troposphere methane lifetime were found to be 7,10 and $10 \%$ in the Atmospheric Chemistry and Climate Model Intercomparison Project (ACCMIP) studies (Young et al., 2013; Voulgarakis et al., 2013). Thus, we find that the chemical rate constant uncertainty is larger than the multi-model spread, which is usually used to give some sense of our uncertainty in our understanding of a quantity. As the models used in these intercomparisons typically use the same rate constants, this rate constant uncertainty is not included in the inter-model spread, and thus the inter-model spread should be considered a lower estimate.

\section{Spatial distribution of uncertainty}

Figure 5 shows the spatial distribution of the total uncertainty in the annual mean $\mathrm{O}_{3}, \mathrm{OH}$ and $\mathrm{CO}$ concentrations for the tropospheric column, the zonal mean and at the surface from the 60 reactions. Similar plots for a large number of other model species are shown in Figs. 6-11. There is a significant degree of inhomogeneity in these uncertainties which respond to a range of factors. The uncertainties in the rate constants are largest in the upper troposphere where the temperatures are coldest and thus furthest from the $298 \mathrm{~K}$ base temperature used to calculate the uncertainties. However, these uncertainties can only manifest if chemistry is the large source or sink for a species in that region. $\mathrm{O}_{3}$ uncertainties are relatively low in the upper troposphere, as it has a large stratospheric source in this region which we have not perturbed (see Sect. 2). $\mathrm{OH}$ uncertainties on the other hand are high $(30 \%)$ in the upper troposphere due to the low temperatures. Over continental regions, the concentration of $\mathrm{CO}$ is not particularly uncertain as the emissions and transport control the concentration. However, over the ocean where emissions are small, the chemistry becomes more important and so uncertainty increases. Uncertainties in $\mathrm{CO}$ are largest in the Southern Hemisphere where direct emission is lower and chemical production from $\mathrm{CH}_{4}$ and other hydrocarbons is significant. In general, uncertainties are largest over remote regions far from recent emissions, especially if they are particularly cold or hot compared to room temperature. 

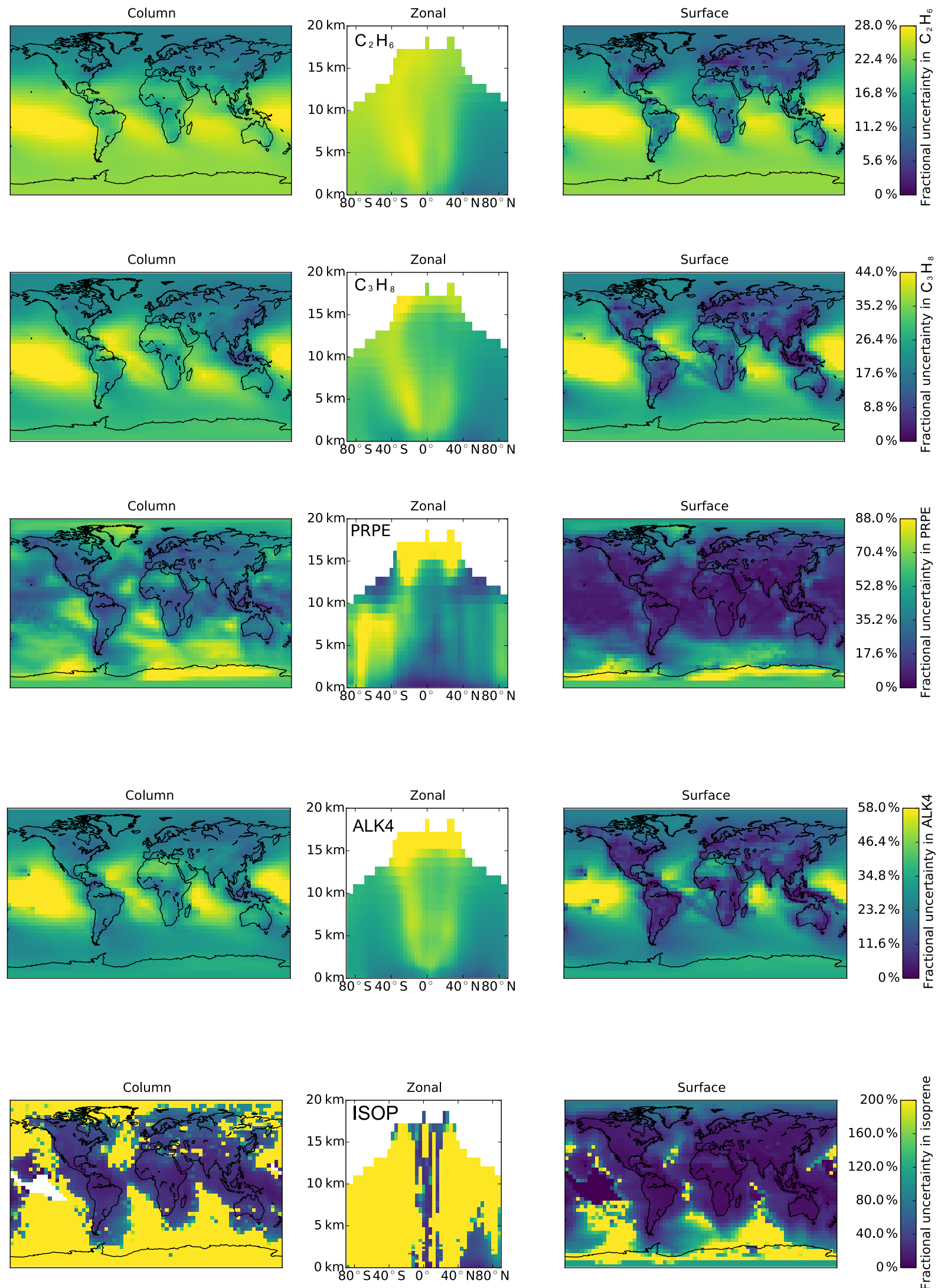

Figure 6. Primary VOCs: total $1 \sigma$ uncertainty in the concentrations of $\mathrm{C}_{2} \mathrm{H}_{6}, \mathrm{C}_{3} \mathrm{H}_{8}$, PRPE ( $\geq \mathrm{C} 3$ alkenes), ALK4 ( $\geq \mathrm{C} 4$ alkanes) and ISOP (isoprene) from the addition in quadrature of the individual reaction uncertainties. "Column" covers the tropospheric column. 

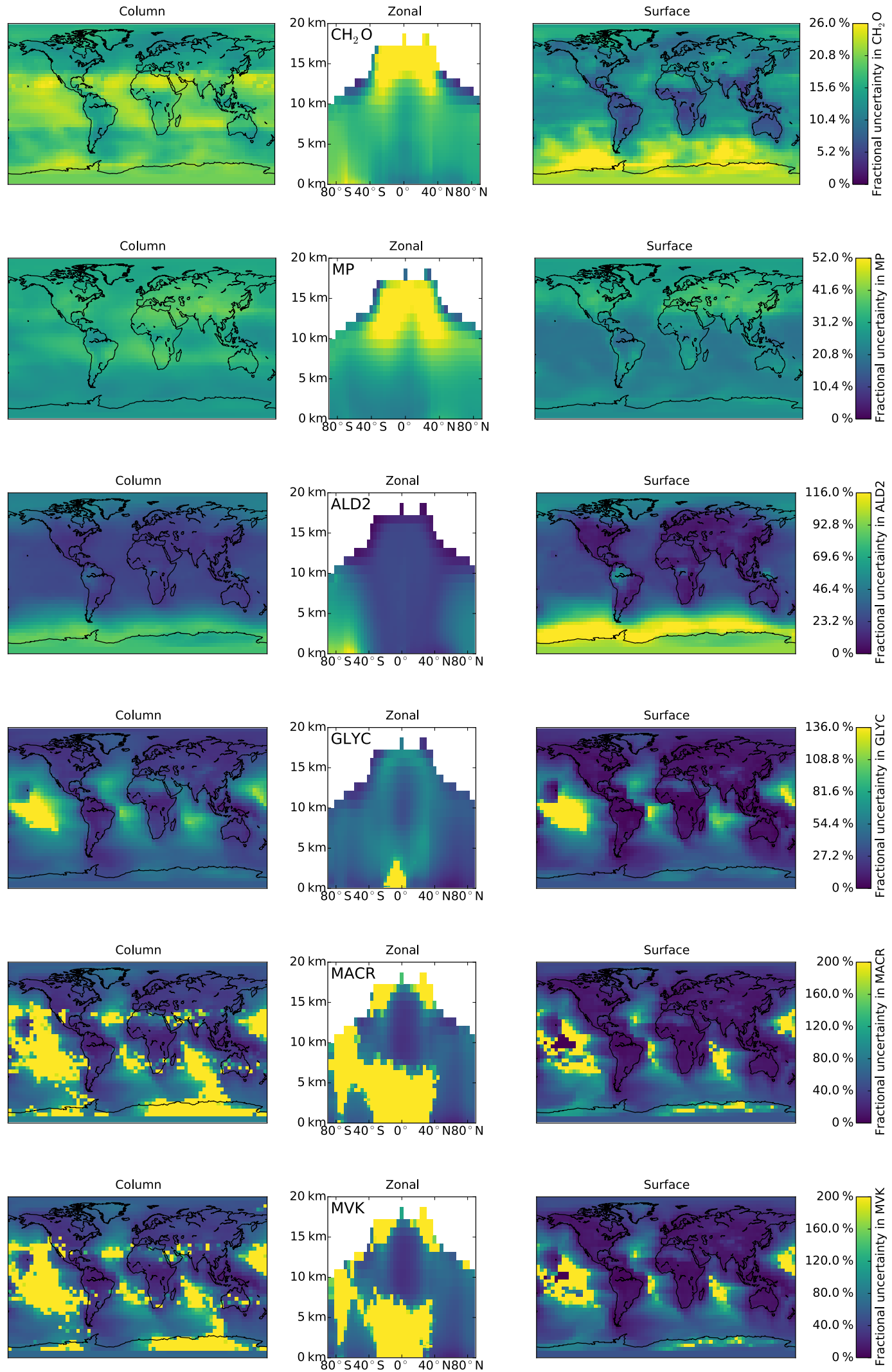

Figure 7. Other organics: total $1 \sigma$ uncertainty in the concentrations of $\mathrm{CH}_{2} \mathrm{O}, \mathrm{MP}$ (methyl hydroperoxide), ALD2 (acetaldehyde), GLYC (glycolaldehyde), MACR (methacrolein) and MKV (methyl vinyl ketone) from the addition in quadrature of the individual reaction uncertainties. "Column" covers the tropospheric column. 

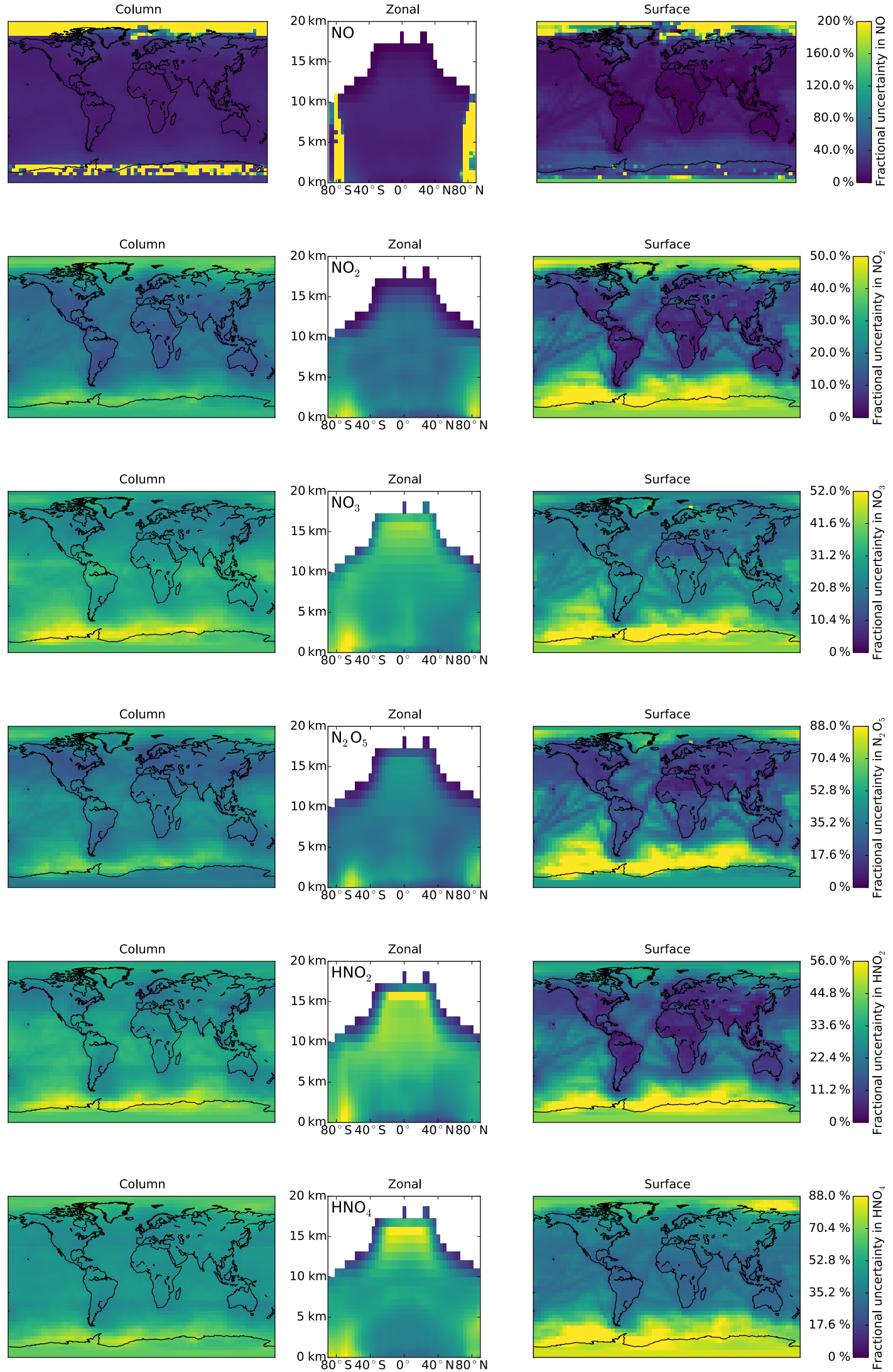

Figure 8. $\mathrm{NO}_{x}$ : total $1 \sigma$ uncertainty in the concentrations of $\mathrm{NO}, \mathrm{NO}_{2}, \mathrm{NO}_{3}, \mathrm{~N}_{2} \mathrm{O}_{5}, \mathrm{HNO}_{2}$ and $\mathrm{HNO}_{4}$ from the addition in quadrature of the individual reaction uncertainties. "Column" covers the tropospheric column. 

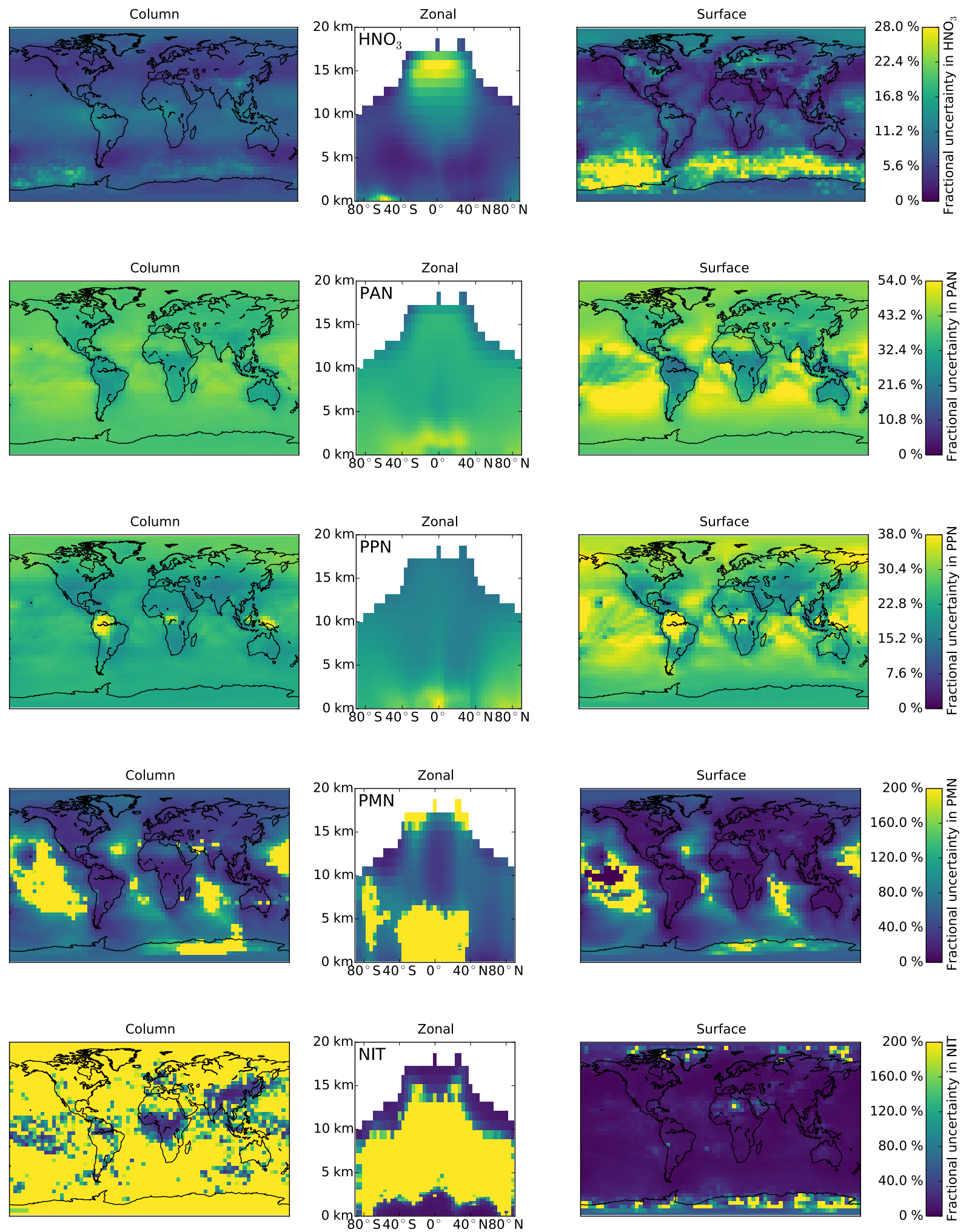

Figure 9. $\mathrm{NO}_{y}$ : total $1 \sigma$ uncertainty in the concentrations of $\mathrm{HNO}_{3}, \mathrm{PAN}$ (peroxyacetyl nitrate), PPN (peroxymethacryloyl nitrate), PMN (peroxymethacryloyl nitrate) and NIT (inorganic aerosol nitrates) from the addition in quadrature of the individual reaction uncertainties. "Column" covers the tropospheric column. 

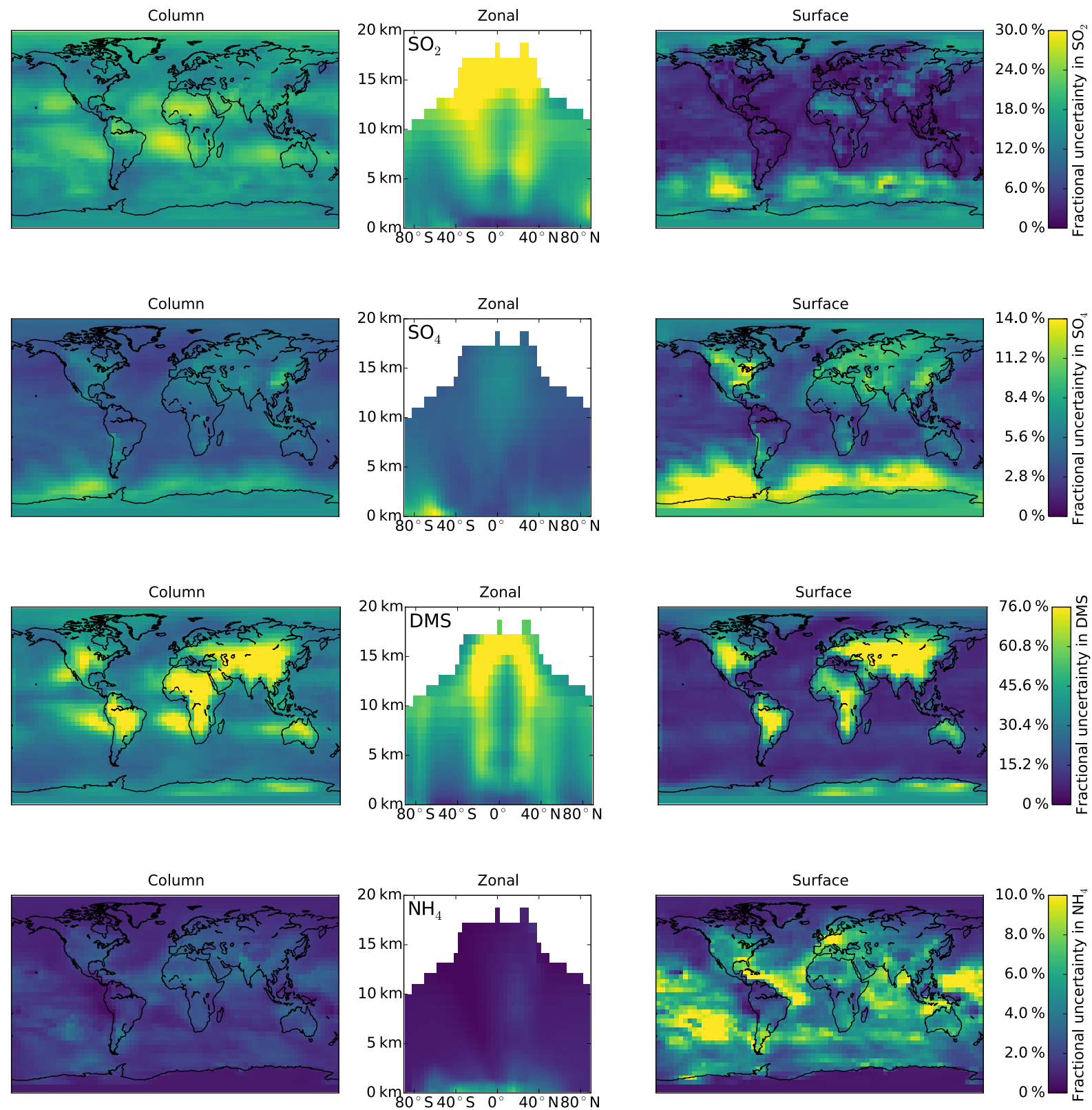

Figure 10. Sulfur and aerosols: total $1 \sigma$ uncertainty in the concentrations of $\mathrm{SO}_{2}, \mathrm{SO}_{4}^{2-}, \mathrm{DMS}$ (dimethyl sulfide) and $\mathrm{NH}_{4}^{+}$from the addition in quadrature of the individual reaction uncertainties. "Column" covers the tropospheric column.

Thus, surface $\mathrm{OH}$ values are more uncertain in the cold remote Southern Ocean than they are in the tropics. Surface $\mathrm{O}_{3}$ values are uncertain in the warm tropics where intense sunlight and high water vapour concentrations lead to a large chemical flux through $\mathrm{O}_{3}$.

Across the full set of simulated compounds (Figs. 6-11), there are even larger uncertainties. For primary emitted hydrocarbons, large uncertainties occur in remote, photochemically active locations such as the tropics where shorter-lived hydrocarbons may be many $\mathrm{OH}$ lifetimes away from sources. Uncertainties in the $\mathrm{OH}$ concentrations thus multiply in these regions, leading to uncertainties of up to $60 \%$ for $\geq \mathrm{C} 4$ alkanes, for example. Secondary products such as $\mathrm{H}_{2} \mathrm{O}_{2}$ and $\mathrm{CH}_{3} \mathrm{OOH}$ also show significant uncertainties of up to $56 \%$ in some locations.

$\mathrm{NO}_{x}$ concentrations close to emission sources are dominated by the emission and transport and thus are not very sensitive to chemical uncertainty (Fig. 8). However, away from these emissions, uncertainties can build up. Uncertainties in the $\mathrm{NO}_{x}$ concentrations at the poles are up to a factor of $40 \%$. Uncertainties in PAN concentrations (Fig. 9) are in general high $(>20 \%)$ in most locations $(\sim 50 \%$ over the 

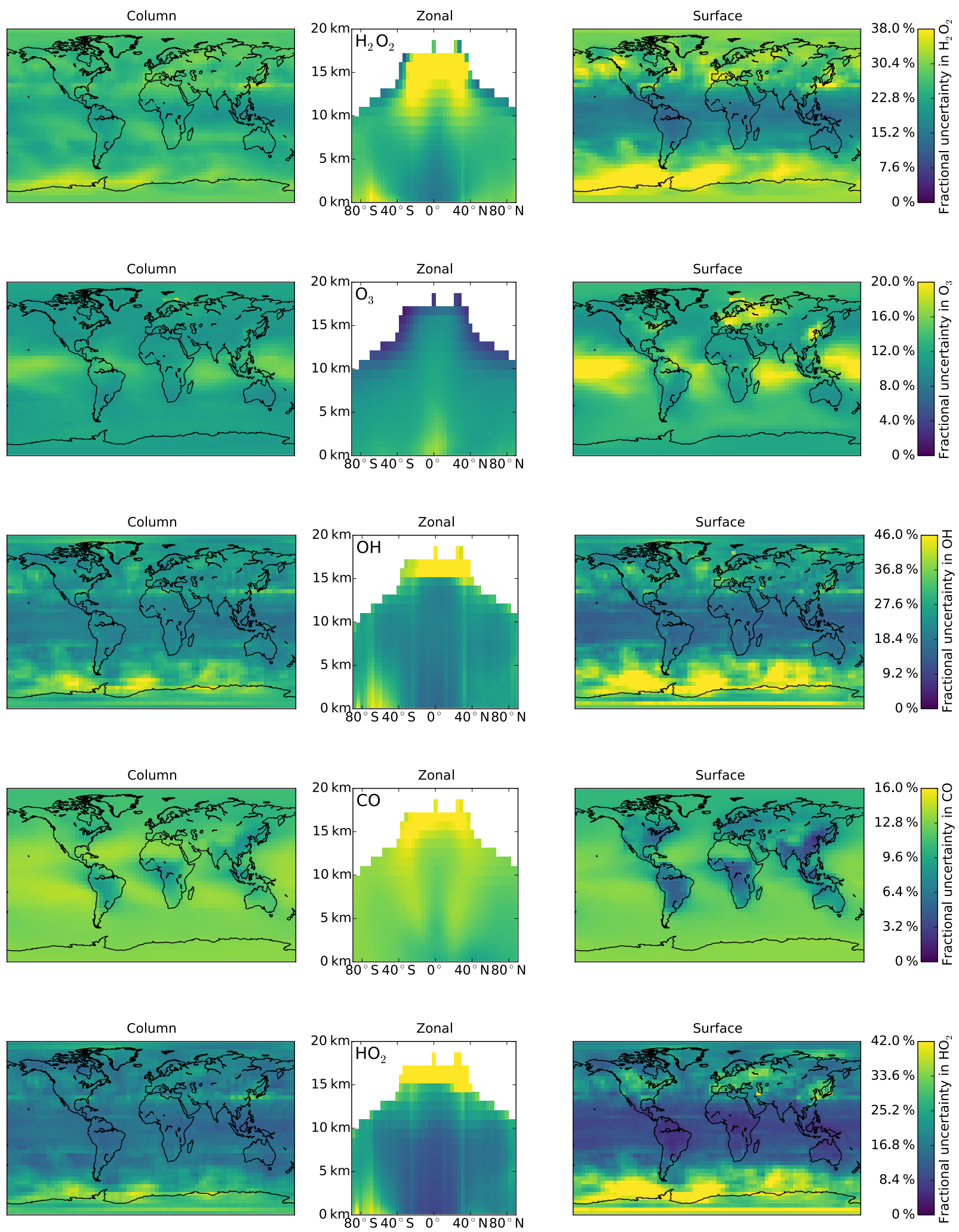

Figure 11. Inorganics: total $1 \sigma$ uncertainty in the concentrations of $\mathrm{H}_{2} \mathrm{O}_{2}, \mathrm{O}_{3}, \mathrm{OH}, \mathrm{CO}$ and $\mathrm{HO}_{2}$ from the addition in quadrature of the individual reaction uncertainties. "Column" covers the tropospheric column. 
(a)

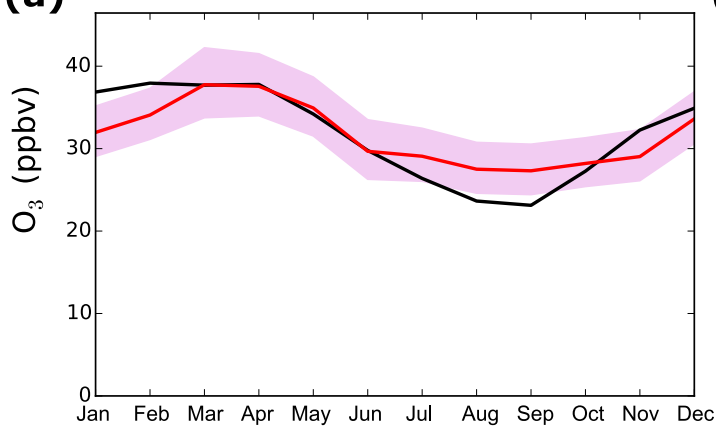

(c)

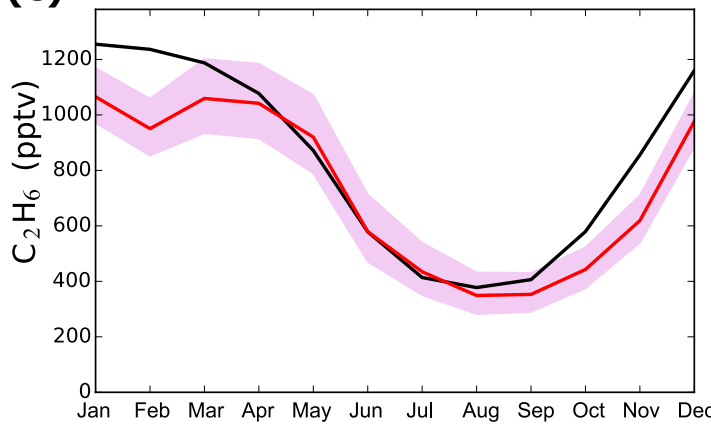

(e)

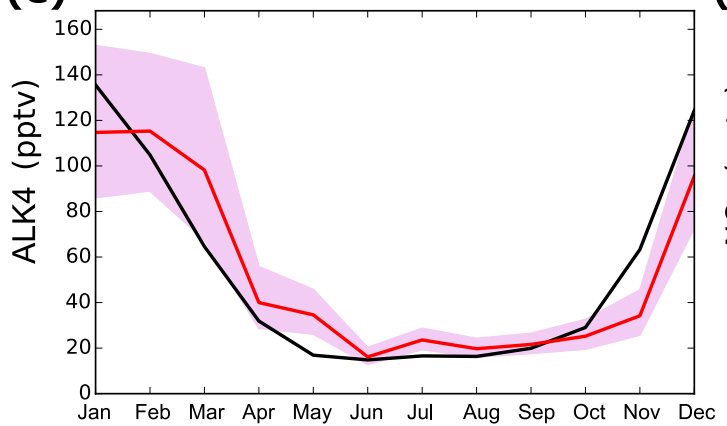

(b)

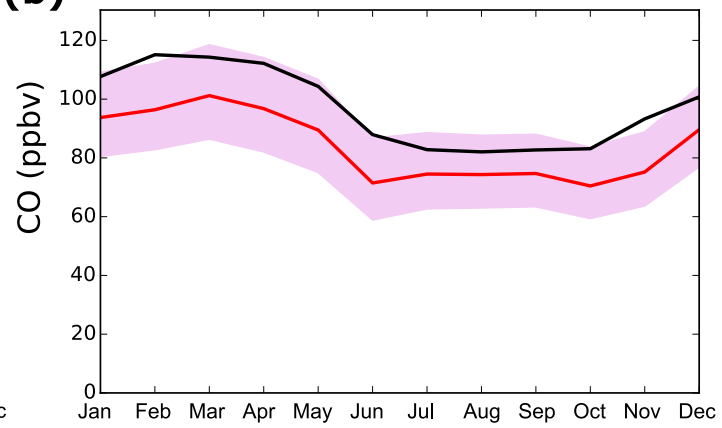

(d)

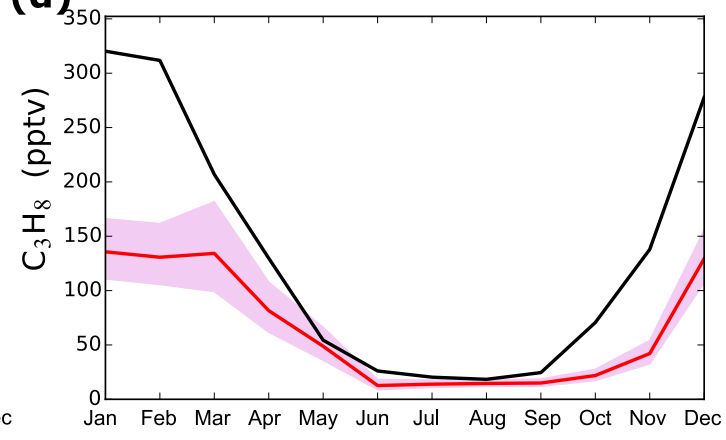

(f)

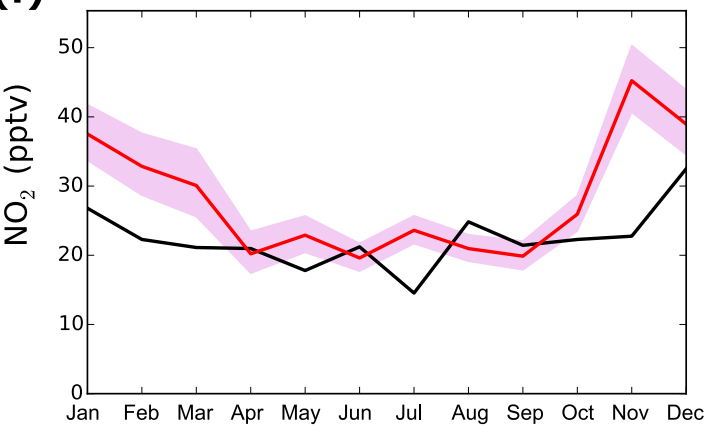

Figure 12. Impact on model/measurement comparisons: modelled (red) and measured (black) annual cycle in monthly mean $\mathrm{O}_{3}$, $\mathrm{CO}, \mathrm{C}_{2} \mathrm{H}_{6}$, $\mathrm{C}_{3} \mathrm{H}_{8}, \mathrm{ALK} 4$ ( $\geq \mathrm{C} 4$ alkanes) and $\mathrm{NO}_{2}$ mixing ratios at Cabo Verde (Carpenter et al., 2011). Shaded area represents the $1 \sigma$ uncertainty from the 60 reactions added together in quadrature.

remote ocean), reflecting the complexity of the chemistry involving uncertainties in both $\mathrm{RO}_{x}$ and $\mathrm{NO}_{x}$ concentrations. Uncertainties in nitric acid (the dominant $\mathrm{NO}_{x}$ sink) concentrations are smaller however $(\sim 5 \%)$, reflecting the mass balance constraint of emissions of $\mathrm{NO}_{x}$ having to balance $\mathrm{NO}_{y}$ sinks. Large variability in nitric acid concentrations in the Southern Ocean reflects non-linearities in aerosol thermodynamics of $\mathrm{HNO}_{3} / \mathrm{NO}_{3}^{-}$partitioning.

$\mathrm{SO}_{2}$ concentrations show the largest uncertainties in the tropical upper troposphere where $\mathrm{OH}$ is also highly uncertain. However, $\mathrm{SO}_{4}^{2-}$ shows much smaller uncertainty, again reflecting mass conservation constraints. $\mathrm{NH}_{4}^{+}$concentrations show little sensitivity to the rate constants analysed. Overall, this suggests that aerosol mass is not particularly sensitive to the gas-phase chemistry examined here.
Overall, we see a complex pattern of uncertainty with geographically highly variable uncertainty.

\section{Implications for model-measurement comparisons}

Comparisons between the predictions made by models and observations underpin the assessment of model fidelity. Deviations between the model and measurements are often used to diagnose model failings. Attributing these differences to uncertainties in the emissions is particularly popular (see, for example, Hartley and Prinn, 1993; Huang et al., 2008). Figure 12 shows observed monthly mean and standard deviations for $\mathrm{CO}, \mathrm{O}_{3}, \mathrm{C}_{2} \mathrm{H}_{6}, \mathrm{C}_{3} \mathrm{H}_{8}, \mathrm{C}_{4} \mathrm{H}_{10}$ and $\mathrm{NO}_{2}$ from the World Meteorological Organisation's Global At- 

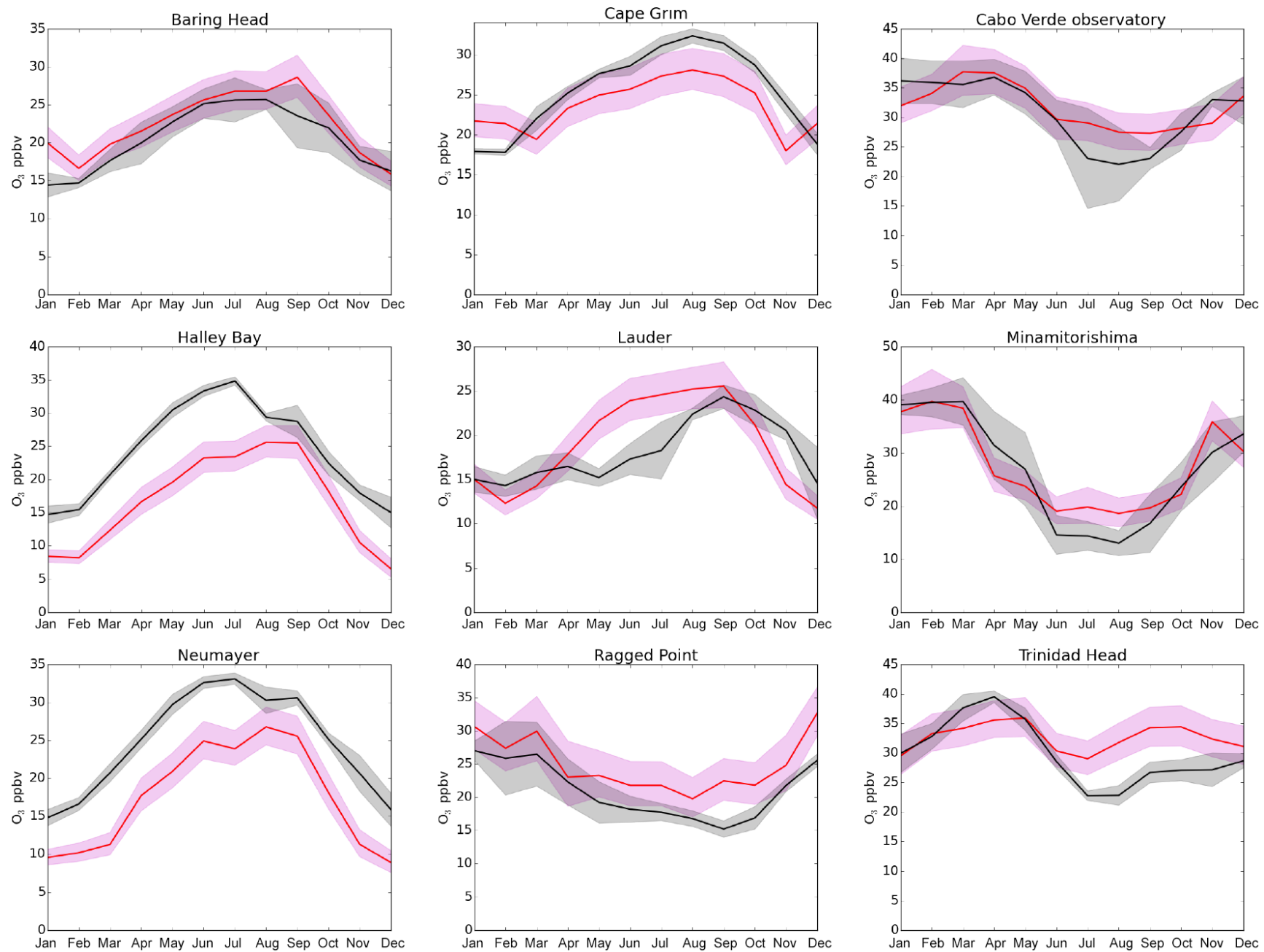

Figure 13. Ozone site comparison: modelled (red) and measured (black) concentrations of ozone at a range of sites. The pink shaded area shows the $1 \sigma$ uncertainty from the chemical kinetics. The error bars represent the $1 \sigma$ uncertainty of these observations. Monthly mean observational data were obtained from Sofen et al. (2016), using multiple years between 2004 and 2010 to create more complete datasets.

mosphere Watch Cape Verde Atmospheric Observatory (Carpenter et al., 2011), overlaid with the base model simulation and the chemical uncertainty $(1 \sigma)$ calculated from the addition in quadrature of the $601 \sigma$ simulations. We chose this location as it is far from recent emissions and thus should show large uncertainties for primary emitted species.

Consistent with Figs. 6-11, the uncertainty in the model calculation ranges from 5 to $30 \%$ depending upon the species. For some of the species $\left(\mathrm{CO}, \mathrm{O}_{3}, \mathrm{C}_{2} \mathrm{H}_{6}, \mathrm{C}_{4} \mathrm{H}_{10}\right)$, much of the difference between the model and the measurements lies within the model $1 \sigma$ uncertainty. For others, such as $\mathrm{C}_{3} \mathrm{H}_{8}$ or $\mathrm{NO}_{2}$, the differences are harder to explain and other processes (emissions, transport, unknown chemistry, etc.) would need to be explored.

Figure 13 shows a comparison of the $\mathrm{O}_{3}$ measured at a number of locations around the world (Sofen et al., 2016) and the model. The shaded areas show the $1 \sigma$ uncertainty due the kinetics for the model and the $1 \sigma$ standard deviation in the measurements. The uncertainty in the model varies between 1 and 5 ppbv depending on location. In some locations, the model uncertainty falls within the measured values. In others, there are significant deviations.

Figures 6-11 show significant changes in uncertainty with changes in the vertical due to increasing uncertainty with reducing temperature. Figure 14 shows a selection of ozonesonde observations from the World Ozone and Ultraviolet Data Centre (WOUDC, 2017) compared to equivalent modelled concentrations and uncertainties. Observations are derived from the surface into the middle troposphere as the temperature drops. The uncertainty thus maximises at around $10 \mathrm{~km}$. Above this, much of the ozone in the model is produced in the stratosphere, which is unperturbed in these simulations. Above this height, the uncertainty in the ozone due to tropospheric chemistry uncertainty reduces.

These comparisons with observations highlight the complexity of attributing model failure to a particular cause. For 

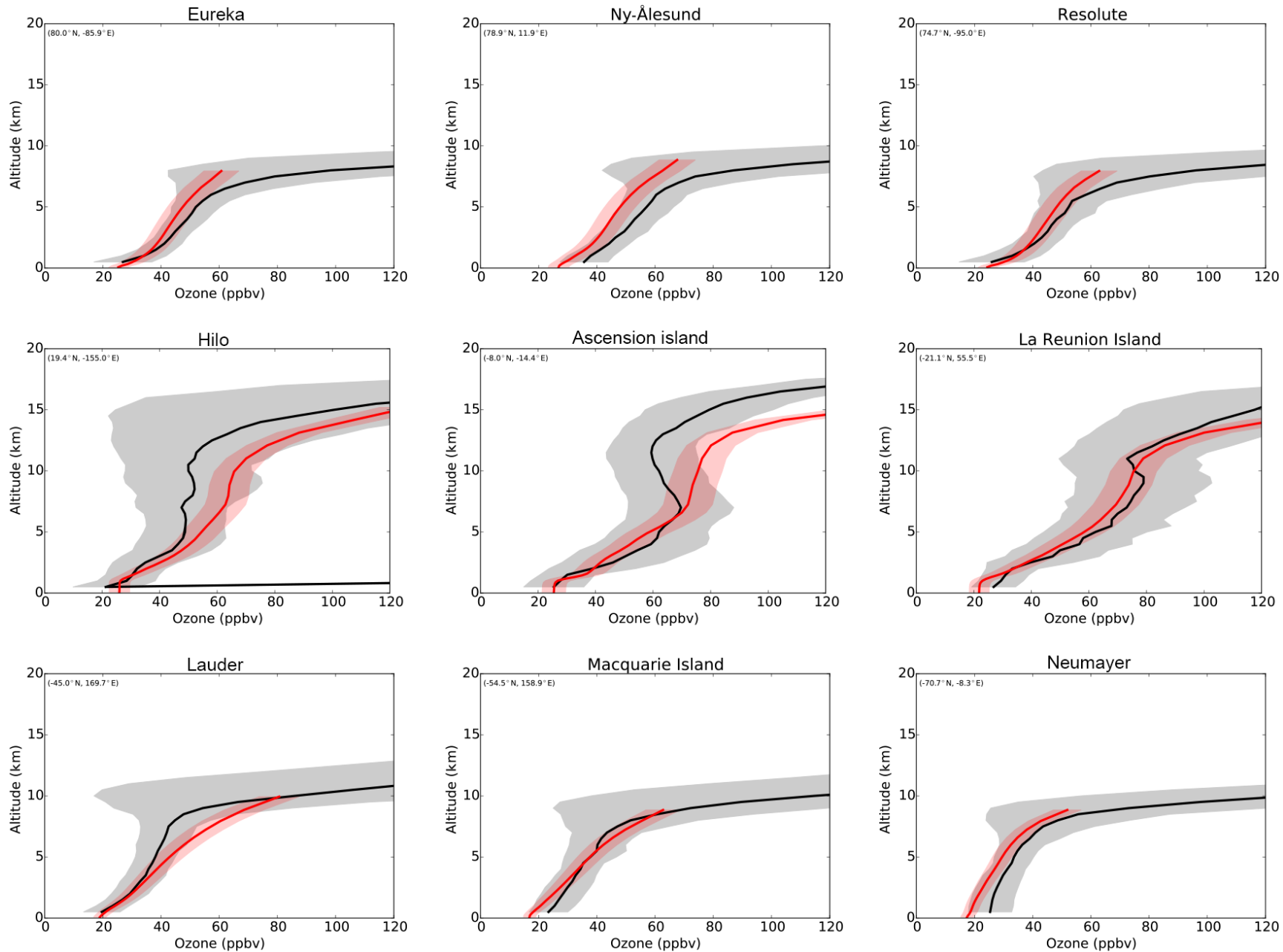

Figure 14. Ozonesondes: comparisons between the variability of annual ozonesonde measurements and model data with uncertainties. The black line shows the annual mean observation data and the shaded gray area shows the range of data. The red line shows the model data and the pink shaded line shows the chemical $1 \sigma$ uncertainty. Observations are obtained from WOUDC (2017).

some locations and some species, the chemical uncertainty can be large. For the same species, in a different location, the uncertainties may be much smaller. Inversion studies which attempt to attribute model failure to a single cause (for example, uncertainties in emissions) need to have a detailed understanding of the magnitude and geographical distribution of the other model errors. We show here that they vary between different species and can be large and highly spatially varying. This should be considered when model inversion studies are undertaken.

\section{Ozone radiative forcing}

We repeat the $601 \sigma$ simulations described above with preindustrial (notionally, the year 1850) emissions (see Sect. 2) to allow us to calculate an uncertainty in the radiative forcing of $\mathrm{O}_{3}$. For each reaction, we calculate the difference in the annual mean tropospheric column $\mathrm{O}_{3}$ (Dobson units) be- tween the present-day and pre-industrial simulations with the rate constant increased to its $1 \sigma$ value. Then, using a linear relationship between change in $\mathrm{O}_{3}$ column and radiative forcing (Stevenson et al., 2013; Young et al., 2013) of $42 \mathrm{~mW} \mathrm{~m}^{-2} \mathrm{DU}^{-1}$, we calculate a radiative forcing associated with the uncertainty associated with each reaction. We estimate an overall uncertainty in the tropospheric $\mathrm{O}_{3}$ radiative forcing in the same way as the other metrics, by adding them together in quadrature. In our base simulations, we calculated the tropospheric $\mathrm{O}_{3}$ radiative forcing to be $412 \mathrm{~mW} \mathrm{~m}^{-2}$, consistent with previous studies ( $410 \pm$ $65 \mathrm{~mW} \mathrm{~m}^{-2}$ ) (Stevenson et al., 2013). Our estimate of the uncertainty in the $\mathrm{O}_{3}$ radiative forcing from rate constant uncertainty is $56 \mathrm{~mW} \mathrm{~m}^{-2}(15 \%)$, with reaction specific detail shown in Fig. 15. Again, the same set of reactions contribute the largest share to the uncertainty in the radiative forcing as in the uncertainty in present-day $\mathrm{O}_{3}$ burden. 


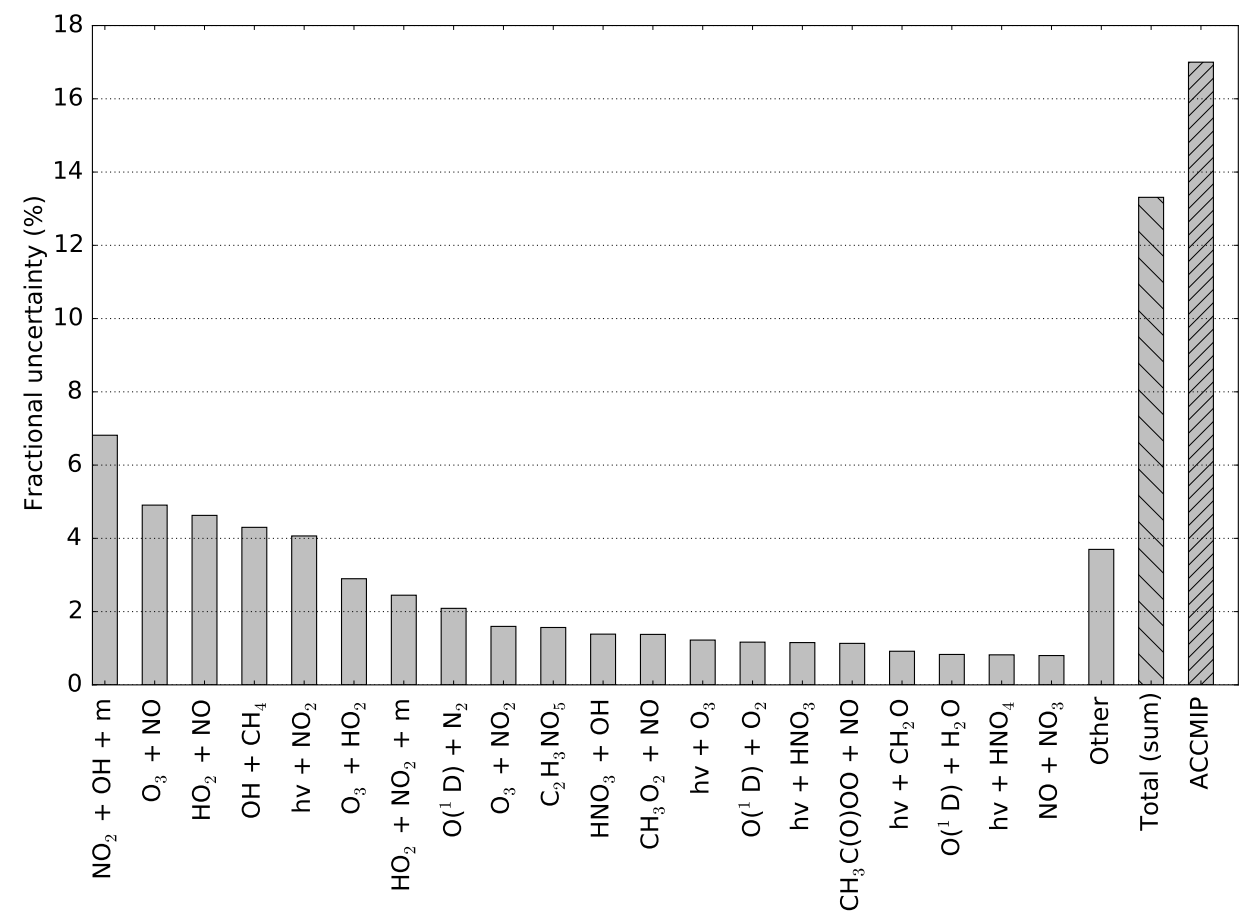

Figure 15. Uncertainties in $\mathrm{O}_{3}$ radiative forcing: absolute fractional uncertainty in tropospheric $\mathrm{O}_{3}$ radiative forcing between the preindustrial and present-day simulations due to rate constant uncertainty. Shown on the left are the 20 most important reactions. "Other" shows the addition in quadrature of the remaining 40 reactions. "Total (sum)" indicates the total fractional uncertainty calculated by adding together the individual uncertainties in quadrature. "ACCMIP" indicates the inter-model spread found from the ACCMIP (Young et al., 2013) study.

This uncertainty estimate of $15 \%$ can be compared to the $17 \%$ spread in the $\mathrm{O}_{3}$ radiative forcing calculated between climate models in the recent ACCMIP (Young et al., 2013) intercomparison (shown in Fig. 15). This spread is usually used as the uncertainty in our understanding of $\mathrm{O}_{3}$ radiative forcing. However, as all of these models use the same JPL or IUPAC recommended rate constants, the inter-model spread does not include the rate constant uncertainty explored here. Given that the rate constant uncertainty is comparable to the inter-model spread, it should be included in future assessments of the uncertainty in $\mathrm{O}_{3}$ radiative forcing. A naive addition in quadrature approach would suggest that the uncertainty on tropospheric $\mathrm{O}_{3}$ radiative forcing should be increased by roughly $30 \%$ to account for this.

\section{Conclusions}

We have shown that the uncertainty in the inorganic rate constants leads to significant ( $>10 \%)$ uncertainties in the concentration of policy-relevant metrics of troposphere composition $\left(\mathrm{O}_{3}\right.$ burden, surface $\mathrm{O}_{3}$, global mean $\mathrm{OH}$, tropospheric $\mathrm{CH}_{4}$ lifetime, $\mathrm{O}_{3}$ radiative forcing) with significantly higher uncertainty in other compounds. This uncertainty may have implications for climate policy through an underestimate of the uncertainty on $\mathrm{O}_{3}$ radiative forcing or significant un- certainties on the $\mathrm{CH}_{4}$ lifetime. This also has implication for how model-measurement disagreements are interpreted. Similar conclusions have been found for regional air quality focussed models (Yang et al., 2000).

The simulations performed here likely provide a lower limit to the chemical uncertainty. We do not explore the impact in uncertainties in organic chemistry (beyond that from the initiation of hydrocarbon oxidation) or in organic mechanisms; we do not included tropospheric bromine, iodine or chlorine chemistry in our analysis or the parameters that define heterogeneous reaction rates. We have neither investigated the impact of rate constant uncertainty on the composition of the stratosphere nor mesosphere, or how this may propagate through to the troposphere. There are also uncertainties in the Henry's law constants used for wet and dry parameterisations, etc. It seems likely therefore that the true chemical uncertainty in the composition of the atmosphere is significantly higher than that found here.

Although it may be challenging, reducing these uncertainties would provide significant benefits. Targeting the top 10 reactions identified here (Fig. 2a) would significantly reduce the overall chemical uncertainties. Despite the fact that the rate constants for these reactions may appear "decided", they provide the basis for determining the composition of the atmosphere. Given the difficulties in reducing the uncertain- 
ties in other areas of the climate system (we will never know the pre-industrial emissions well, etc.), a redoubled effort to reduce rate constant uncertainty appears to be a relatively straightforward methodology to improve our understanding of atmospheric composition.

Data availability. The GEOS-Chem model is available from http: //www.geos-chem.org. The updates made to the code for this project are available from https://doi.org/10.15124/4d161daa-ffc4410b-a4b6-600615b29679 (Evans and Newsome, 2017).

Competing interests. The authors declare that they have no conflict of interest.

Acknowledgements. Ben Newsome was supported by a NERC studentship (NE/L501761/1). This work was supported by the NERC-funded BACCHUS project (NE/L01291X/1). The Cape Verde Atmospheric Observatory is supported by the NERC-funded ORC3 project (NE/K004980/1) and by the National Centre for Atmospheric Science. GEOS-Chem (http://www.geos-chem.org) is a community effort, and we wish to thank all involved in the development of the model. We would also thank all the JPL and IUPAC panels for their efforts in compiling atmospheric rate constants.

Edited by: Thomas von Clarmann

Reviewed by: Rolf Sander and one anonymous referee

\section{References}

Atkinson, R., Baulch, D. L., Cox, R. A., Crowley, J. N., Hampson, R. F., Hynes, R. G., Jenkin, M. E., Rossi, M. J., and Troe, J.: Evaluated kinetic and photochemical data for atmospheric chemistry: Volume $\mathrm{I}-$ gas phase reactions of $\mathrm{O}_{x}, \mathrm{HO}_{x}$, $\mathrm{NO}_{x}$ and $\mathrm{SO}_{x}$ species, Atmos. Chem. Phys., 4, 1461-1738, https://doi.org/10.5194/acp-4-1461-2004, 2004.

Bey, I., Jacob, D. J., Yantosca, R. M., Logan, J. A., Field, B. D., Fiore, A. M., Li, Q., Liu, H. Y., Mickley, L. J., and Schultz, M. G.: Global modeling of tropospheric chemistry with assimilated meteorology: Model description and evaluation, J. Geophys. Res.-Atmos., 106, 23073-23095, https://doi.org/10.1029/2001JD000807, 2001.

Burkholder, J. B., Sander, S. P., Abbatt, J., Barker, J. R., , Huie, R. E., Kolb, C. E., Kurylo, M. J., Orkin, V. L., Wilmouth, D., and Wine, P.: Chemical Kinetics and Photochemical Data for Use in Atmospheric Studies, Evaluation No. 18, Jet Propulsion Laboratory, available at: http://jpldataeval.jpl.nasa.gov/ (last access: 1 October 2017), 2015.

Carpenter, L. J., Fleming, Z. L., Read, K. A., Lee, J. D., Moller, S. J., Hopkins, J. R., Purvis, R. M., Lewis, A. C., Müller, K., Heinold, B., Herrmann, H., Fomba, K. W., van Pinxteren, D., Müller, C., Tegen, I., Wiedensohler, A., Müller, T., Niedermeier, N., Achterberg, E. P., Patey, M. D., Kozlova, E. A., Heimann, M., Heard, D. E., Plane, J. M. C., Mahajan, A., Oetjen, H., Ingham,
T., Stone, D., Whalley, L. K., Evans, M. J., Pilling, M. J., Leigh, R. J., Monks, P. S., Karunaharan, A., Vaughan, S., Arnold, S. R., Tschritter, J., Pöhler, D., Frieß, U., Holla, R., Mendes, L. M., Lopez, H., Faria, B., Manning, A. J., and Wallace, D. W. R.: Seasonal characteristics of tropical marine boundary layer air measured at the Cape Verde Atmospheric Observatory, J. Atmos. Chem., 67, 87-140, https://doi.org/10.1007/s10874-011-9206-1, 2011.

Dockery, D. W., Pope, C. A., Xu, X., Spengler, J. D., Ware, J. H., Fay, M. E., Ferris, B. G. J., and Speizer, F. E.: An Association between Air Pollution and Mortality in Six U.S. Cities, N. Engl. J. Med., 329, 1753-1759, https://doi.org/10.1056/NEJM199312093292401, 1993.

Evans, M. J. and Newsome, B.: Model Code associated with Newsome and Evans Impact of uncertainties in inorganic chemical rate constants on tropospheric composition and ozone radiative forcing, https://doi.org/10.15124/4d161daa-ffc4-410b-a4b6600615b29679, 2017.

Goldstein, A. H. and Galbally, I. E.: Known and Unexplored Organic Constituents in the Earth's Atmosphere, Environ. Sci Technol., 41, 1514-1521, https://doi.org/10.1021/es072476p, 2007.

Hartley, D. and Prinn, R.: Feasibility of determining surface emissions of trace gases using an inverse method in a threedimensional chemical transport model, J. Geophys. Res.-Atmos., 98, 5183-5197, https://doi.org/10.1029/92JD02594, 1993.

Huang, J., Golombek, A., Prinn, R., Weiss, R., Fraser, P., Simmonds, P., Dlugokencky, E. J., Hall, B., Elkins, J., Steele, P., Langenfelds, R., Krummel, P., Dutton, G., and Porter, L.: Estimation of regional emissions of nitrous oxide from 1997 to 2005 using multinetwork measurements, a chemical transport model, and an inverse method, J. Geophys. Res.-Atmos., 113, D17313, https://doi.org/10.1029/2007JD009381, 2008.

Hudman, R. C., Moore, N. E., Mebust, A. K., Martin, R. V., Russell, A. R., Valin, L. C., and Cohen, R. C.: Steps towards a mechanistic model of global soil nitric oxide emissions: implementation and space based-constraints, Atmos. Chem. Phys., 12, 7779-7795, https://doi.org/10.5194/acp-12-7779-2012, 2012.

IPCC: Climate Change 2013: The Physical Science Basis. Contribution of Working Group I to the Fifth Assessment Report of the Intergovernmental Panel on Climate Change, edited by: Stocker, T. F., Qin, D., Plattner, G.-K., Tignor, M., Allen, S. K., Boschung, J., Nauels, A., Xia, Y., Bex, V., and Midgley, P. M., Cambridge University Press, Cambridge, UK and New York, NY, USA, 1535 pp., 2013.

Jacobson, M. Z. and Turco, R. P.: SMVGEAR: A sparse-matrix, vectorized Gear code for atmospheric models, Atmos. Environ. 28, 273-284, 1994.

Lin, X., Trainer, M., and Liu, S. C.: On the nonlinearity of the tropospheric ozone production, J. Geophys. Res.-Atmos., 93, 1587915888, https://doi.org/10.1029/JD093iD12p15879, 1988.

McLinden, C., Olsen, S., Hannegan, B., Wild, O., Prather, M., and Sundet, J.: Stratospheric ozone in 3-D models: A simple chemistry and the cross-tropopause flux, J. Geophys. Res., 105, 14653-14665, https://doi.org/10.1029/2000JD900124, 2000.

Murray, L. T., Jacob, D. J., Logan, J. A., Hudman, R. C., and Koshak, W. J.: Optimized regional and interannual variability of lightning in a global chemical transport model constrained by 
LIS/OTD satellite data, J. Geophys. Res.-Atmos., 117, D20307, https://doi.org/10.1029/2012JD017934, 2012.

Park, R. J., Jacob, D. J., Chin, M., and Martin, R. V.: Sources of carbonaceous aerosols over the United States and implications for natural visibility, J. Geophys. Res.-Atmos., 108, 4355, https://doi.org/10.1029/2002JD003190, 2003.

Parrella, J. P., Jacob, D. J., Liang, Q., Zhang, Y., Mickley, L. J., Miller, B., Evans, M. J., Yang, X., Pyle, J. A., Theys, N., and Van Roozendael, M.: Tropospheric bromine chemistry: implications for present and pre-industrial ozone and mercury, Atmos. Chem. Phys., 12, 6723-6740, https://doi.org/10.5194/acp12-6723-2012, 2012.

Sherwen, T., Evans, M. J., Carpenter, L. J., Andrews, S. J., Lidster, R. T., Dix, B., Koenig, T. K., Sinreich, R., Ortega, I., Volkamer, R., Saiz-Lopez, A., Prados-Roman, C., Mahajan, A. S., and Ordóñez, C.: Iodine's impact on tropospheric oxidants: a global model study in GEOS-Chem, Atmos. Chem. Phys., 16, 11611186, https://doi.org/10.5194/acp-16-1161-2016, 2016.

Sindelarova, K., Granier, C., Bouarar, I., Guenther, A., Tilmes, S., Stavrakou, T., Müller, J.-F., Kuhn, U., Stefani, P., and Knorr, W.: Global data set of biogenic VOC emissions calculated by the MEGAN model over the last 30 years, Atmos. Chem. Phys., 14, 9317-9341, https://doi.org/10.5194/acp-14-9317-2014, 2014.

Sofen, E. D., Alexander, B., and Kunasek, S. A.: The impact of anthropogenic emissions on atmospheric sulfate production pathways, oxidants, and ice core $\Delta^{17} \mathrm{O}\left(\mathrm{SO}_{4}^{2-}\right)$, Atmos. Chem. Phys., 11, 3565-3578, https://doi.org/10.5194/acp-113565-2011, 2011.

Sofen, E. D., Bowdalo, D., Evans, M. J., Apadula, F., Bonasoni, P., Cupeiro, M., Ellul, R., Galbally, I. E., Girgzdiene, R., Luppo, S., Mimouni, M., Nahas, A. C., Saliba, M., and Tørseth, K.: Gridded global surface ozone metrics for atmospheric chemistry model evaluation, Earth Syst. Sci. Data, 8, 4159, https://doi.org/10.5194/essd-8-41-2016, 2016.

Stevenson, D. S., Young, P. J., Naik, V., Lamarque, J.-F., Shindell, D. T., Voulgarakis, A., Skeie, R. B., Dalsoren, S. B., Myhre, G., Berntsen, T. K., Folberth, G. A., Rumbold, S. T., Collins, W. J., MacKenzie, I. A., Doherty, R. M., Zeng, G., van Noije, T. P. C., Strunk, A., Bergmann, D., Cameron-Smith, P., Plummer, D. A., Strode, S. A., Horowitz, L., Lee, Y. H., Szopa, S., Sudo, K., Nagashima, T., Josse, B., Cionni, I., Righi, M., Eyring, V., Conley, A., Bowman, K. W., Wild, O., and Archibald, A.: Tropospheric ozone changes, radiative forcing and attribution to emissions in the Atmospheric Chemistry and Climate Model Intercomparison Project (ACCMIP), Atmos. Chem. Phys., 13, 3063-3085, https://doi.org/10.5194/acp-13-3063-2013, 2013. van der Werf, G. R., Randerson, J. T., Giglio, L., Collatz, G. J., Mu, M., Kasibhatla, P. S., Morton, D. C., DeFries, R. S., Jin, Y., and van Leeuwen, T. T.: Global fire emissions and the contribution of deforestation, savanna, forest, agricultural, and peat fires (1997-2009), Atmos. Chem. Phys., 10, 11707-11735, https://doi.org/10.5194/acp-10-11707-2010, 2010.

Voulgarakis, A., Naik, V., Lamarque, J.-F., Shindell, D. T., Young, P. J., Prather, M. J., Wild, O., Field, R. D., Bergmann, D., CameronSmith, P., Cionni, I., Collins, W. J., Dalsøren, S. B., Doherty, R. M., Eyring, V., Faluvegi, G., Folberth, G. A., Horowitz, L. W., Josse, B., MacKenzie, I. A., Nagashima, T., Plummer, D. A., Righi, M., Rumbold, S. T., Stevenson, D. S., Strode, S. A., Sudo, K., Szopa, S., and Zeng, G.: Analysis of present day and future $\mathrm{OH}$ and methane lifetime in the ACCMIP simulations, Atmos. Chem. Phys., 13, 2563-2587, https://doi.org/10.5194/acp13-2563-2013, 2013.

WOUDC: WOUDC Ozone Monitoring Community, World Meteorological Organization - Global Atmosphere Watch Program (WMO-GAW), https://doi.org/10.14287/10000001, 2017.

Yang, Y.-J., Wilkinson, J. G., Talat Odman, M., and Russell, A. G.: Air Pollution Modeling and Its Application XIII, Ozone Sensitivity and Uncertainty Analysis Using DDM-3D in a Photochemical Air Quality Model, Springer US, Boston, MA, USA, 183-194, https://doi.org/10.1007/978-1-4615-4153-0_19, 2000.

Young, P. J., Archibald, A. T., Bowman, K. W., Lamarque, J.-F., Naik, V., Stevenson, D. S., Tilmes, S., Voulgarakis, A., Wild, O., Bergmann, D., Cameron-Smith, P., Cionni, I., Collins, W. J., Dalsøren, S. B., Doherty, R. M., Eyring, V., Faluvegi, G., Horowitz, L. W., Josse, B., Lee, Y. H., MacKenzie, I. A., Nagashima, T., Plummer, D. A., Righi, M., Rumbold, S. T., Skeie, R. B., Shindell, D. T., Strode, S. A., Sudo, K., Szopa, S., and Zeng, G.: Preindustrial to end 21st century projections of tropospheric ozone from the Atmospheric Chemistry and Climate Model Intercomparison Project (ACCMIP), Atmos. Chem. Phys., 13, 2063 2090, https://doi.org/10.5194/acp-13-2063-2013, 2013. 